Novel Pt electrocatalysts: multifunctional composite supports for enhanced corrosion resistance and improved $\mathrm{CO}$ tolerance

Topics in Catalysis, 61(12) (2018) 1300-1312.

Vass Á, Borbáth I, Bakos I, Pászti Z, Sajó IE, Tompos A

DOI: $10.1007 / \mathrm{s} 11244-018-0988-0$

(C) Springer Science+Business Media, LLC, part of Springer Nature 2018

Corresponding author: Irina Borbáth

Article history:

Published online: 11 May 2018 


\title{
Novel Pt electrocatalysts: multifunctional composite supports for enhanced corrosion resistance and improved CO tolerance
}

\author{
Á. Vass ${ }^{1}$, I. Borbáth $^{1 *}$, I. Bakos ${ }^{1}$, Z. Pászti ${ }^{1}$, I.E. Sajó ${ }^{2}$, A. Tompos ${ }^{1}$ \\ ${ }^{1}$ Institute of Materials and Environmental Chemistry, Research Centre for Natural Sciences, \\ Hungarian Academy of Sciences, H-1117 Budapest, Magyar tudósok körútja 2, Hungary \\ ${ }^{2}$ University of Pécs, Szentágothai Research Centre, Pécs, H-7624, Ifjúság str. 20. Hungary
}

\begin{abstract}
The electrochemical peculiarities of novel $20 \mathrm{wt} \% \mathrm{Pt}$ electrocatalysts supported on $\mathrm{Ti}_{0.6} \mathrm{Mo}_{0.4} \mathrm{O}_{2}-\mathrm{C}$ composite materials in low-potential $\mathrm{CO}$ oxidation reaction (LPCOR) were investigated. The oxidation of $\mathrm{CO}$ on the Mo-containing Pt-based catalyst commences at exceptionally low potential values (ca. $100 \mathrm{mV}$ ). The results suggest that only $\mathrm{CO}$ adsorbed on specific Pt sites, where Pt and Mo atoms are in atomic closeness, can be oxidised below $400 \mathrm{mV}$ potential. When the weakly bounded $\mathrm{CO}$ is oxidized, some hydrogen adsorption can take place on the released surface, although this amount is much smaller than in the case of a CO-free Pt surface. The Pt/ $\mathrm{Ti}_{0.6} \mathrm{Mo}_{0.4} \mathrm{O}_{2}-\mathrm{C}$ catalyst loses its activity in LPCOR when Mo becomes oxidized (above ca. $400 \mathrm{mV}$ ). Accordingly, presence of Mo species in lower oxidation state than $6+$ is supposed to have crucial role in CO oxidation. Nevertheless, rereduction of oxidized Mo species formed above $400 \mathrm{mV}$ is strongly hindered when adsorbed $\mathrm{CO}$ species are still present. Note that $\mathrm{CO}_{\mathrm{ads}}$ species can be completely removed only above $550 \mathrm{mV}$. Oxidized Mo species can be re-reduced and the activity in the LPCOR can be restored if the platinum surface is CO-free. Clear correlation between the so-called "prepeak", the molybdenum redox phenomenon and the $\mathrm{CO}$ tolerance of the $20 \mathrm{wt} \%$ $\mathrm{Pt} / \mathrm{Ti}_{0.6} \mathrm{Mo}_{0.4} \mathrm{O}_{2}-\mathrm{C}$ system was established. Better performance of the $\mathrm{Pt} / \mathrm{Ti}_{0.6} \mathrm{Mo}_{0.4} \mathrm{O}_{2}-\mathrm{C}$ electrocatalyst compared to commercially available reference $\mathrm{Pt} / \mathrm{C}$ and state-of-art $\mathrm{CO}$ tolerant PtRu/C (Quintech) catalysts was also demonstrated.
\end{abstract}

Keywords Conducting Ti-based mixed oxides, $\mathrm{TiMoO}_{\mathrm{x}}$, Composite materials, Pt electrocatalysts, CO-tolerance

\footnotetext{
* Corresponding author, Tel.: +36 1382 6916, email: borbath.irina@ttk.mta.hu, address: H-1519 Budapest, P.O.Box 286, Hungary (Irina Borbáth)
} 


\section{Introduction}

Considerable interest has been devoted in recent years to develop suitable electrode materials for the possible application in Polymer Electrolyte Membrane Fuel Cells (PEMFC). For fuel cells, state-of-art systems contain large quantities of platinum supported on carbon black. However, active carbon tends to corrode under the fast load change conditions [1]. It is therefore important to explore alternative materials that can provide improved stability across the anticipated potential/pH window compared to carbon [2].

Moreover, $\mathrm{Pt} / \mathrm{C}$ electrocatalysts suffer from other drawback regarding their poor tolerance to $\mathrm{CO}$ poisoning, as a small amount of $\mathrm{CO}$ is inevitably present in fuels obtained by reforming of hydrocarbons. This problem has led to an intensive effort to develop so-called CO-tolerant anode catalysts. Accordingly, current research on fuel cell catalysts focuses on developing durable, CO-tolerant and efficient electrocatalysts, which are the most compelling practical needs for real-life applications.

Materials composed of $\mathrm{Pt}$ nanoparticles (NPs), $\mathrm{TiO}_{2}$ and carbon materials are identified as efficient electrocatalysts since they combine the high conductivity of carbon and corrosion resistance of the oxide with the synergistic effect between metal oxides and Pt [3]. Highly graphitic carbons provide a good backbone for retaining the original nanoscale and uniform $\mathrm{TiO}_{2}$ coatings $(<10 \mathrm{~nm})$ without sintering during heat treatment [4]. The strong interaction between the $\mathrm{TiO}_{2}$ coating on carbon and the Pt results in drastically increased electrochemically active Pt surface area and inhibits the agglomeration and corrosion of the metal NPs [5]. Composite support materials, such as $\mathrm{TiO}_{2}-\mathrm{C}$ also show improved stability in accelerated aging tests [6-8].

Doping of titania with n-type dopants such as transition metals (e.g., W, Nb and Ta [912]) results in materials with high electrochemical stability and unique CO-tolerance, along with an increase of the electric conductivity. However, conductivities of these materials remain still substantially lower than that of carbon. In Ref. [13] the $\mathrm{Ti}_{0.7} \mathrm{~W}_{0.3} \mathrm{O}_{2}$ mixed oxide was mixed with carbon powder in an attempt to increase its conductivity required for electrocatalyst applications.

Due to their enhanced $\mathrm{CO}$ tolerance tungsten- and molybdenum-oxide supported $\mathrm{Pt}$ electrocatalysts have been considered as potential candidates at the PEMFC anode [14-17]. A very high electrocatalytic activity observed at $\mathrm{MoO}_{\mathrm{x}}-\mathrm{Pt}$ catalyst for the hydrogen oxidation reaction (HOR, anode reaction) in the presence of $100 \mathrm{ppm} \mathrm{CO}$ was attributed to chemical surface reaction of adsorbed CO with Mo surface oxides [18,19]. 
However, their application is limited by their instability due to leaching of the nonnoble component at high potentials in both alkaline and acidic conditions [20]. The latter is particularly important, as PEMFC works under acidic conditions. The leaching can not only decrease catalyst activity and $\mathrm{CO}$ tolerance but may also result in reduced electrolyte performance due to encapsulation of the leached components in the membrane.

Despite to the beneficial co-catalytic effect of molybdenum in electrooxidation of $\mathrm{CO}$ and alcohols, its behaviour is very complex since it may be present in several oxidation states and might form distinct soluble species and various oxides [21]. In the literature the information about the stability of Mo-containing catalysts is still controversial. While some studies report the occurrence of the dissolution of non-alloyed molybdenum after only a few voltammetric cycles [22,23], other investigations have shown the presence of stable molybdenum species even after several cycles at potentials between 0.0 and $1.2 \mathrm{~V}$ [24]. Upon using the $\mathrm{Pt}_{4} \mathrm{Mo} / \mathrm{C}$ catalysts Papakonstantinou et al. [25] proposed that $\mathrm{CO}$ oxidation process was accompanied with oxidation of the $\mathrm{Mo}^{\mathrm{x}+}(\mathrm{x}=4$ or 5$)$ species into $\mathrm{MoO}_{3}$, which dissolved and then, upon negative current application, reactivated into catalytically active sites via electrodeposition and subsequent reduction. However, using $\mathrm{Pt}_{x} \mathrm{Mo}_{y} / \mathrm{C}$ catalysts [26] it has been stated that the intermetallic bonding stabilizes Mo on the surface under potentials of practical interest for use in fuel cell anodes. Thus, it has been suggested [26] that at ca. $0.4 \mathrm{~V}$ and higher there is oxidation of Mo to the $(6+)$ state, which in the pure metal results in dissolution, but in the alloy this oxidation state is stabilized in the surface by the intermetallic bonding. The effectiveness of the $\mathrm{MoO}_{\mathrm{x}} @ \mathrm{Pt}$ core-shell and well-defined $\mathrm{Pt}_{0.8} \mathrm{Mo}_{0.2}$ alloy electrocatalysts to improve anode performance with higher $\mathrm{CO}$ tolerance and durability was demonstrated [27,28]. It has been shown that leaching may be mitigated with a well-ordered alloy or a core-shell catalyst architecture with a seemingly pure Pt surface.

It has been demonstrated that [29,30] strong metal support interaction between Pt and $\mathrm{MoO}_{3}$ results in significant improvement of the stability of the electrocatalysts. Recently, the combination of the highly stable $\mathrm{TiO}_{2}$ with $\mathrm{MoO}_{\mathrm{x}}$, was reported to have high electronic conductivity and relative stability in acid solutions. Accordingly, the multifunctional $\mathrm{Ti}_{0.7} \mathrm{Mo}_{0.3} \mathrm{O}_{2}$ support material was successfully applied for Pt-based catalysts for the oxygen reduction reaction (ORR, cathode reaction) [31,32]. Recently the use of Mo-doped titanium suboxide $\left(\mathrm{Ti}_{3} \mathrm{O}_{5}-\mathrm{Mo}\right)$ has been demonstrated as an alternative carbon-free catalyst support for the ORR in low-temperature fuel cells [33]. The $\mathrm{Pt} / \mathrm{Ti}_{3} \mathrm{O}_{5}-\mathrm{Mo}$ catalyst exhibits excellent electrocatalytic activity and stability toward the ORR. A deep accelerated potential cycling 
between 0 and $1.2 \mathrm{~V}$ vs RHE up to 5000 cycles demonstrated the remarkable stability of this catalyst.

Furthermore, in acidic solutions hydrogen molybdenum bronze of type $\mathrm{H}_{\mathrm{x}} \mathrm{MoO}_{3}$ could also be formed by the "spillover" of hydrogen dissociated on Pt metal sites towards Mo, that may have a contribution to the enhanced catalytic activity in $\mathrm{CO}$ and methanol electrooxidation [34-36]. The intercalation of hydrogen into the $\mathrm{MoO}_{3}$ lattice is accompanied by reduction of the metal ions and formation of $\mathrm{H}_{\mathrm{x}} \mathrm{MoO}_{3}$ with $\mathrm{Mo}$ in mixed valent state $(5+/ 6+)$ [34]. Moreover, strong metal support interaction required between $\mathrm{Pt}$ and $\mathrm{MoO}_{3}$ for the formation of $\mathrm{H}_{\mathrm{x}} \mathrm{MoO}_{3}$ leads to significant enhancement in electrocatalytic activity and stability [34].

In our recent studies [37-39] stabilization of tungsten was achieved by incorporation into the rutile- $\mathrm{TiO}_{2}$ lattice, while the conductivity was ensured by a mixed oxide-activated carbon composite. A new synthesis method optimized for preparation of $\mathrm{Ti}_{0.7} \mathrm{~W}_{0.3} \mathrm{O}_{2}-\mathrm{C}$ composites with the $\mathrm{Ti}_{0.7} \mathrm{~W}_{0.3} \mathrm{O}_{2} / \mathrm{C}$ mass ratio of 50:50 and almost exclusive tungsten incorporation into the rutile lattice was developed. Enhanced CO tolerance of novel $40 \mathrm{wt} . \%$ $\mathrm{Pt} / \mathrm{Ti}_{0.7} \mathrm{~W}_{0.3} \mathrm{O}_{2}-\mathrm{C}$ electrocatalysts compared to the commercial $\mathrm{Pt} / \mathrm{C}$ or state-of-art $\mathrm{CO}$ tolerant $\mathrm{PtRu} / \mathrm{C}$ (Quintech, $\mathrm{Pt}=20 \mathrm{wt} . \%, \mathrm{Ru}=10 \mathrm{wt} . \%$ ) catalysts were also evidenced [37]. In fact, performance even exceeding that of the $\mathrm{PtRu} / \mathrm{C}$ benchmark was observed.

The electrochemical activity and CO-tolerance was confirmed by measurements in a single fuel-cell test device as well, where it was shown that $100 \mathrm{ppm}$ CO concentration in the $\mathrm{H}_{2}$ fuel caused $140 \mathrm{mV}$ voltage loss at $1 \mathrm{~A} \mathrm{~cm}^{-2}$ current density upon using the $40 \mathrm{wt} . \%$ $\mathrm{Pt} / \mathrm{Ti}_{0.7} \mathrm{M}_{0.3} \mathrm{O}_{2}-\mathrm{C}(\mathrm{M}=\mathrm{W}, \mathrm{Mo})$ catalysts, while in the case of the $\mathrm{Pt} / \mathrm{C}$ and $\mathrm{PtRu} / \mathrm{C}$ the loss was 360 and $240 \mathrm{mV}$, respectively, confirming the advantageous properties of the new type of composite supported electrocatalysts [40].

The described results demonstrate that the idea of combining the high surface area and good conductivity of active carbon with the excellent stability of $\mathrm{TiO}_{2}$ and with the beneficial co-catalytic properties of $\mathbf{M}$ dopant oxides $(\mathrm{M}=\mathrm{W}, \mathrm{Mo})$ is indeed a feasible way to develop a new generation of Pt-based electrocatalysts for PEM fuel cells. Moreover, leaching of the non-noble metal modifiers can be effectively suppressed by exclusive incorporation of the dopant into the $\mathrm{TiO}_{2}$-rutile lattice.

Preparation of $20 \mathrm{wt} . \% \mathrm{Pt} / \mathrm{Ti}_{(1-\mathrm{x})} \mathrm{Mo}_{\mathrm{x}} \mathrm{O}_{2}-\mathrm{C}(\mathrm{x}=0.2$ - 0.4) composite supported catalysts with the $\mathrm{Ti}_{(1-\mathrm{x})} \mathrm{Mo}_{\mathrm{x}} \mathrm{O}_{2} / \mathrm{C}$ mass ratio 75:25 were described in our recent paper [41]. It has been demonstrated that different Mo species have critical importance on the electrocatalytic performance both in hydrogen oxidation and $\mathrm{CO}$ tolerance. The importance of Mo ions 
incorporated into the rutile lattice was underlined. Non-incorporated Mo species are not stable upon applying a wide cyclic polarization window and as a consequence they are removed gradually, resulting in unstable electrocatalytic performance. The Ti/Mo atomic ratio of 80/20 has been suggested as an optimal composition having the largest ratio of incorporated/nonincorporated Mo species.

In the present work our aim is to give a more elaborate insight into the behaviour of the $\mathrm{Ti}_{(1-\mathrm{x})} \mathrm{Mo}_{\mathrm{x}} \mathrm{O}_{2}-\mathrm{C}$ composite supported $\mathrm{Pt}$ catalysts. The primary emphasis is on investigating the electrochemical peculiarities of the system in order to establish a connection between the so-called "pre-peak", the molybdenum redox phenomenon and the CO tolerance of the $\mathrm{Ti}_{0.6} \mathrm{Mo}_{0.4} \mathrm{O}_{2}-\mathrm{C}$ composite supported $\mathrm{Pt}$ catalyst in comparison with commercially available $\mathrm{Pt} / \mathrm{C}$ and $\mathrm{CO}$-tolerant $\mathrm{PtRu} / \mathrm{C}$ catalysts.

\section{Experimental}

\subsection{Preparation of $\mathrm{Ti}_{0.6} \mathrm{Mo}_{0.4} \mathrm{O}_{2}$-C support materials and Pt catalysts}

Titanium-isopropoxide ( $\mathrm{Ti}(\mathrm{O}-\mathrm{i}-\mathrm{Pr})_{4}$, Aldrich, 97\%) and ammonium heptamolybdate tetrahydrate $\left(\left(\mathrm{NH}_{4}\right)_{6} \mathrm{Mo}_{7} \mathrm{O}_{24} \times 4 \mathrm{H}_{2} \mathrm{O}\right.$, Merck, 99\%) were used as Ti and Mo precursor compounds.

In order to prepare the composite support containing mixed oxide with $\mathrm{Ti} / \mathrm{Mo}$ atomic ratio of $60 / 40\left(\mathrm{Ti}_{0.6} \mathrm{Mo}_{0.4} \mathrm{O}_{2}\right)$ and activated carbon in a mass ratio of 75:25 between the oxide and the carbon, first transparent acidic $\mathrm{TiO}_{2}$ colloidal solution was made by adding concentrated $\mathrm{HNO}_{3}$ to a vigorously stirred mixture of Ti(O-i-Pr $)_{4}$ and distilled water. Active carbon (CABOT, Black Pearls 2000, specific surface area: $1475 \mathrm{~m}^{2} / \mathrm{g}$ ) was added after $4 \mathrm{~h}$ stirring at room temperature (RT). In order to facilitate the formation of rutile nuclei, the mixture was aged at RT for 4 days. After the aging, molybdenum precursor compound $\left(\left(\mathrm{NH}_{4}\right)_{6} \mathrm{Mo}_{7} \mathrm{O}_{24} \times 4 \mathrm{H}_{2} \mathrm{O}\right)$ was added and the solution was evaporated at $80^{\circ} \mathrm{C}$. The powder was dried at $80^{\circ} \mathrm{C}$ overnight. Detailed description of the synthesis procedure can be found in our previous studies $[40,41]$. The obtained powder has been submitted to high-temperature treatment $\left(600^{\circ} \mathrm{C}, 8 \mathrm{~h}, \mathrm{Ar}\right.$ flow).

The support material was loaded with $20 \mathrm{wt} . \% \mathrm{Pt}$ via the previously used modified $\mathrm{NaBH}_{4}$-assisted ethylene-glycol reduction-precipitation method [40,41]. The materials were washed with water by centrifugation and dried at $80^{\circ} \mathrm{C}$ overnight.

\subsection{Electrochemical characterization}


Electrochemical measurements were carried out at RT in a standard three-electrode electrochemical cell. The supporting electrolyte was $0.5 \mathrm{M} \mathrm{H}_{2} \mathrm{SO}_{4}$, the counter electrode was a platinum wire, the reference electrode was a hydrogen electrode immersed in the same electrolyte as the working electrode and all potentials are given on the RHE scale. The working electrode for both static and rotating disc electrode (RDE) measurement was prepared by dipping a drop of catalyst ink on a freshly polished glassy carbon electrode $(\mathrm{d}=$ $0.3 \mathrm{~cm}$, geometric surface area $\mathrm{A}=0.0707 \mathrm{~cm}^{2}$ ), and air-drying at RT for $30 \mathrm{~min}$. Pt loading of the electrode was $10 \mu \mathrm{g} \mathrm{cm}^{-2}$. For the catalyst ink $5 \mathrm{mg}$ catalyst sample was suspended in 4 $\mathrm{ml} \mathrm{H} \mathrm{H}_{2} \mathrm{O}+1 \mathrm{ml}$ isopropanol $+20 \mu \mathrm{l}$ Nafion solution (D520 Nafion Dispersion - Alcohol based $1000 \mathrm{EW}$ at $5 \mathrm{wt} \%$, DuPont ${ }^{\mathrm{TM}} \mathrm{Nafion}^{\circledR}$ ).

Before the measurements the electrolyte was purged with Ar for at least 20 minutes then 10 cyclic voltammogramms (CVs) were recorded with $100 \mathrm{mV} \mathrm{s}^{-1}$ sweep rate between 50 and $1000 \mathrm{mV}$ for conditioning the catalysts.

For the electrochemical characterization of the catalyst samples two methods were applied: Ar purged and $\mathrm{H}_{2}$ purged $\mathrm{CO}_{\text {ads }}$ stripping voltammetry.

In a case of Ar purged $\mathrm{CO}_{\text {ads }}$ stripping measurements after conditioning the electrode, the potential was set to $50 \mathrm{mV}$ and $\mathrm{CO}$ gas was fed into the electrolyte solution for 20 minutes, then the liquid was purged with $\mathrm{Ar}$ for another 20 minutes. Ar purged $\mathrm{CO}_{\mathrm{ads}}-$ stripping voltammetry measurements were done using three different potential programs. For the whole series of measurements the potential programs used can be seen in the insert of corresponding figures.

The effect of $\mathrm{CO}$ tolerant behaviour on hydrogen oxidation reaction was also investigated by RDE method. A modified $\mathrm{H}_{2}$ purged $\mathrm{CO}_{\text {ads }}$ stripping voltammetry coupled with HOR on RDE was used in this study.

First $\mathrm{CO}$ gas was bubbled into the electrolyte solution for 30 minutes then $\mathrm{H}_{2}$ for 30 minutes while maintaining the potential at $50 \mathrm{mV}$. At the end of the $\mathrm{H}_{2}$ purging the working electrode was polarized to $250 \mathrm{mV}$ and held for 3 minutes at this potential. Then it was polarized to $0 \mathrm{mV}$, and $3 \mathrm{CVs}$ were recorded between $0 \mathrm{mV}$ and $250 \mathrm{mV}$ with $10 \mathrm{mV} \mathrm{s} \mathrm{s}^{-1}$ sweep rate while the disc electrode was rotated at $625 \mathrm{rpm}$ and the $\mathrm{H}_{2}$ gas was bubbled to the solution. This process was repeated with the difference in the anodic potential limits: $350 \mathrm{mV}$, $450 \mathrm{mV}, 550 \mathrm{mV}$ and $1000 \mathrm{mV}$.

For comparison as reference commercially available $20 \mathrm{wt} . \% \mathrm{Pt} / \mathrm{C}$ (Quintech, C-20-Pt, on Vulcan; denoted hereafter as $\mathrm{Pt} / \mathrm{C}$ ) and $\mathrm{PtRu} / \mathrm{C}$, considered as the state-of-art CO-tolerant 
electrocatalyst (Quintech, C-20-/10-Pt/Ru, Pt= $20 \mathrm{wt} \%, \mathrm{Ru}=10 \mathrm{wt} \%$ on Vulcan; denoted hereafter as $\mathrm{PtRu} / \mathrm{C}$ ) were also studied by the same method as described above.

\subsection{Physical characterization}

X-ray photoelectron spectroscopy (XPS) measurements were carried out using an EA125 electron spectrometer manufactured by OMICRON Nanotechnology GmbH (Germany). The photoelectrons were excited by unmonochromatized $\mathrm{MgKa}(1253.6 \mathrm{eV})$ radiation. Spectra were recorded in the Constant Analyser Energy mode of the energy analyser with $30 \mathrm{eV}$ pass energy resulting in a spectral resolution around $1 \mathrm{eV}$. The powder catalyst samples were suspended in isopropanol then some of this suspension was dried to a standard OMICRON sample plate. Binding energies were referenced to the main component of the $\mathrm{C} 1 \mathrm{~s}$ spectrum of the support (graphite at $284.4 \mathrm{eV}$ binding energy). Data were processed using the CasaXPS software package [42].

\section{Results and Discussion}

Fig. 1 compares the $\mathrm{CVs}$ and the $\mathrm{CO}_{\mathrm{ads}}$ stripping voltammograms recorded on the $\mathrm{Pt} / \mathrm{Ti}_{0.6} \mathrm{Mo}_{0.4} \mathrm{O}_{2}-\mathrm{C}, \mathrm{PtRu} / \mathrm{C}$ and $\mathrm{Pt} / \mathrm{C}$ catalysts. The base voltammograms for $\mathrm{PtRu} / \mathrm{C}$ and $\mathrm{Pt} / \mathrm{C}$ catalysts (Fig. 1a) show the characteristic hydrogen (i) and oxygen (iii) adsorption/desorption regions [43] and shall not be discussed here. A typical CV of Pt with the classical features of the underpotentially deposited hydrogen adsorption/desorption between $50 \mathrm{mV}$ and $350 \mathrm{mV}$ (i) along with a redox peak between 380 and $530 \mathrm{mV}$ (ii) was observed on the Mo-containing composite supported sample presented in Fig. 1a. According to the literature $[34,44]$ the appearance of strong redox peaks in the voltammograms clearly confirms that there is an active interface between the Pt NPs and Mo-containing support.

Comparison of the $\mathrm{CO}_{\text {ads }}$ stripping behaviour of the $\mathrm{Pt} / \mathrm{Ti}_{0.6} \mathrm{Mo}_{0.4} \mathrm{O}_{2}-\mathrm{C}$ electrocatalyst to the reference commercial $\mathrm{Pt} / \mathrm{C}$ and $\mathrm{PtRu} / \mathrm{C}$ catalysts (see Fig. 1b) demonstrates increased $\mathrm{CO}$ tolerance of the composite supported catalyst. As can be seen in Fig. 1b, on the $\mathrm{Pt} / \mathrm{C}$ catalysts the main $\mathrm{CO}$ oxidation peak is located at ca. $795 \mathrm{mV}$ (vi), while the corresponding peak in the case of the CO-tolerant $\mathrm{PtRu} / \mathrm{C}$ catalysts is around $505 \mathrm{mV}$ (iv). The $\mathrm{CO}_{\mathrm{ads}}$ stripping voltammograms for $\mathrm{PtRu} / \mathrm{C}$ and $\mathrm{Pt} / \mathrm{C}$ catalysts (Fig. 1b) resemble those commonly observed in the literature [43] with the onset potential for $\mathrm{CO}$ oxidation $\left(\mathrm{E}_{\mathrm{CO} \text {, onset }}\right)$ of about 255 and $625 \mathrm{mV}$, respectively. As shown in Fig. $1 \mathrm{~b}$ the $\mathrm{CO}_{\text {ads }}$ stripping voltammogram for the $\mathrm{Pt} / \mathrm{Ti}_{0.6} \mathrm{Mo}_{0.4} \mathrm{O}_{2}-\mathrm{C}$ catalyst displays two clear oxidation features: the main anodic peak at 705 $\mathrm{mV}(\mathrm{v})$, and a "pre-peak" consisting of two small overlapping peaks centered at ca. 215 (ii') 
and $400 \mathrm{mV}$ (ii), which may be attributed to partial oxidation of weakly adsorbed CO (ii') and oxidation of Mo surface species (ii), respectively; details on their position (Fig. 4a) as well as their relationship to the $\mathrm{CO}$ tolerant behaviour will be discussed below. According to the Arpurged voltammograms, the $\mathrm{E}_{\mathrm{CO}}$, onset on the composite supported catalyst is not higher than $50-100 \mathrm{mV}$. It is necessary to mention, that the early onset of CO oxidation as a "pre-peak" is typical for Pt-based catalysts containing Ti, Ta, W, and Mo suboxides [33,45].
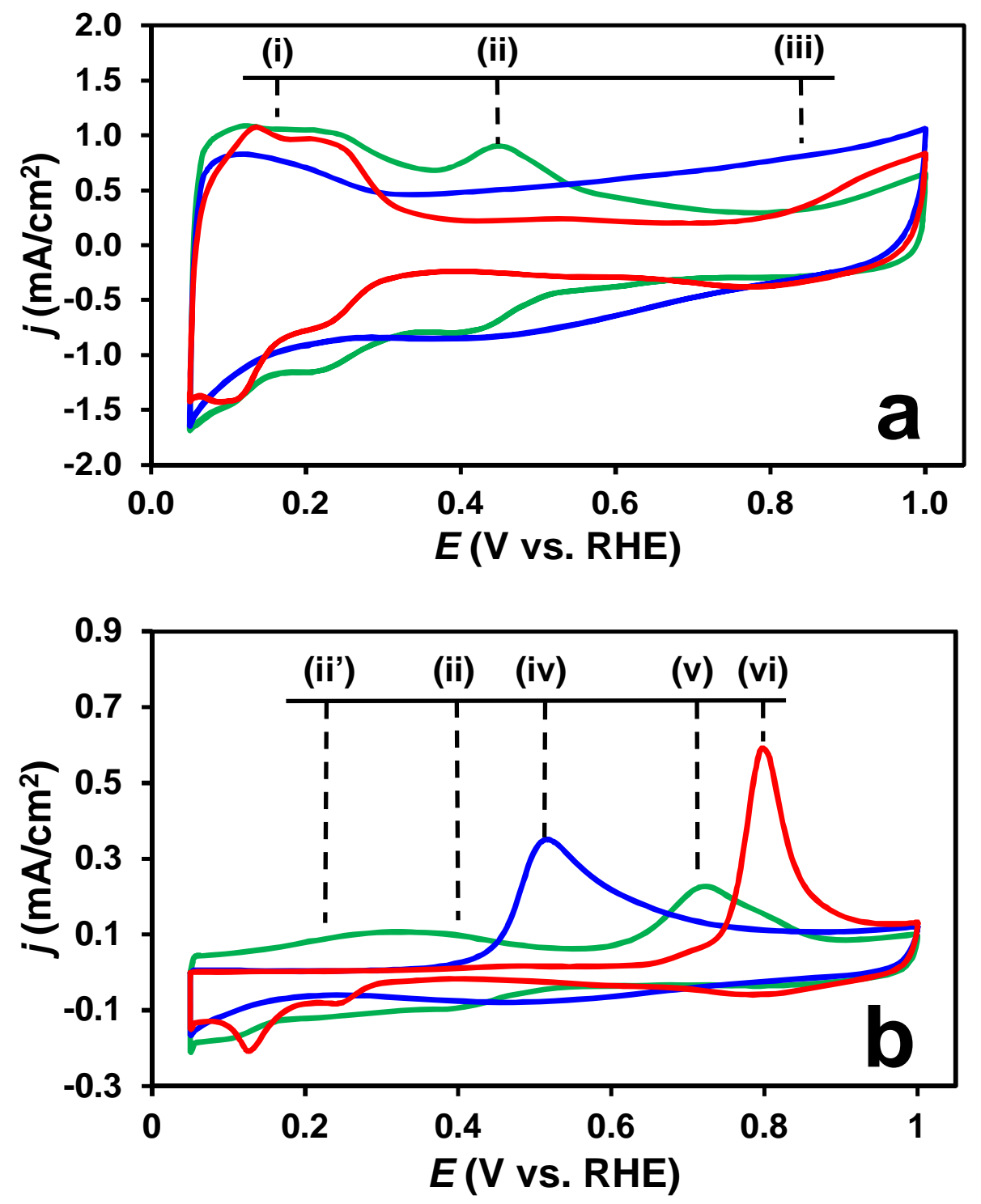

Fig. 1. Cyclic (a) and Ar-purged $\mathrm{CO}_{\text {ads }}$ stripping (b) voltammograms of the $\mathrm{Pt} / \mathrm{Ti}_{0.6} \mathrm{Mo}_{0.4} \mathrm{O}_{2}-\mathrm{C}$ (green line), $\mathrm{PtRu} / \mathrm{C}$ (blue line) and $\mathrm{Pt} / \mathrm{C}$ (red line) catalysts. Recorded in $0.5 \mathrm{M} \mathrm{H}_{2} \mathrm{SO}_{4}, \mathrm{~T}=$ $25{ }^{\circ} \mathrm{C}$, at sweep rate $100 \mathrm{mV} \mathrm{s}^{-1}$ (a) and $10 \mathrm{mV} \mathrm{s}^{-1}$ (b). Marks of the anodic peaks: (i) hydrogen desorption; (ii') - oxidation of weakly bonded CO; (ii) - oxidation of Mo surface 
species; (iii) - oxygen adsorption; (iv), (v) and (vi) - oxidation of strongly bonded CO on $\mathrm{PtRu} / \mathrm{C}, \mathrm{Pt} / \mathrm{Ti}_{0.6} \mathrm{Mo}_{0.4} \mathrm{O}_{2}-\mathrm{C}$ and $\mathrm{Pt} / \mathrm{C}$, respectively.

It has been demonstrated by Differential Electrochemical Mass Spectrometry (DEMS) that both peaks observed in the $\mathrm{CO}_{\mathrm{ads}}$ stripping voltammograms ("pre-peak" and the main peak) are related to the $\mathrm{CO}_{2}$ production $[44,46]$. At the same time, DEMS results presented for Pt-electrodes modified with Mo reveal that $\mathrm{CO}_{2}$ formation starts around $0.15 \mathrm{~V}$ overlapping with the onset of Mo oxidation [46]. Although the mechanism by which Mo promotes the oxidation of the adsorbed $\mathrm{CO}$ in the Pt surface is not yet known, it is generally considered to be of a bifunctional nature in conjunction with electronic effect (influence of the catalyst support on the electronic state of active phase) [47]. In agreement with the bifunctional mechanism, the co-catalytic activity is supposed to be due to the good redox properties of the oxides involved.

Nevertheless, identifying the co-catalytically active molybdenum ionic state is a challenging task. Usually, molybdenum oxides do not exist in a single phase but in mixedvalence oxides $\left(\mathrm{MoO}_{x}\right)$ [35]. The specific assignment of the Mo oxidation peak is not consensual, but the comparison with Pourbaix diagram for Mo indicates that this redox behaviour is due to the $\mathrm{Mo}^{4+} \oplus \mathrm{Mo}^{6+}$ couple [26]. However, according to in situ X-ray absorption spectroscopy (XAS) studies of the Mo K edge of PtMo/C catalysts it has been demonstrated by Mukerjee et al. [24] that at potentials as low as $0.0 \mathrm{~V}$ Mo is present in $\mathrm{Mo}^{5+}$ oxidation state as some sort of a hydrated oxide close to $\mathrm{MoO}(\mathrm{OH})_{2}$. Confirming the electrochemical results direct spectroscopic evidence of change in the oxidation state $\mathrm{Mo}^{5+} / \mathrm{Mo}^{6+}$ between 0.0 and $0.54 \mathrm{~V}$ was provided [24,47]. The $\mathrm{MoO}(\mathrm{OH})_{2}$ species $[24-26,48]$ or in general the hydrogen Mo bronzes $\mathrm{H}_{x} \mathrm{MoO}_{3}[49,50]$ are considered as the reactive moiety with adsorbed CO. It has been proposed that $\mathrm{CO}$ species, which are adsorbed on Pt atoms adjacent to Mo atoms, react easily with the $\mathrm{OH}$ species of the $\mathrm{MoO}(\mathrm{OH})_{x}$ toward the formation of $\mathrm{CO}_{2}$ at potentials lower than $0.25 \mathrm{~V}$, cleaning this way the Pt active site from $\mathrm{CO}$ poisoning species $[25,35,51]$ :

$$
\left(\mathrm{MoO}_{x}\right)-\mathrm{OH}_{\mathrm{ads}}+\mathrm{Pt}-(\mathrm{CO})_{\mathrm{ads}} \rightarrow \mathrm{CO}_{2}+\mathrm{Pt}+\mathrm{MoO}_{x}+\mathrm{H}^{+}+\mathrm{e}^{-}
$$

Subsequently, the empty space created on the $\mathrm{Mo}^{\mathrm{x}+}$ species facilitates the heterolytic dissociative adsorption of water and the regeneration of $\mathrm{MoO}(\mathrm{OH})_{x}$ [25]. Thus, the unique properties of Mo-containing catalysts at low potentials $(<0.2 \mathrm{~V})$ depend on the oxidation state 
of the Mo surface species and specifically on the reactive $\mathrm{OH}$ species of $\mathrm{MoO}(\mathrm{OH})_{X}$ and their ability to spontaneously dissociate $\mathrm{H}_{2} \mathrm{O}$. Papakonstantinou et al. [25] proposed that at potentials higher than $0.2 \mathrm{~V}$ the average oxidation state of $\mathrm{Mo}^{\mathrm{x}+}$ is larger than $5+$, resulting in the deactivation of the Mo species due to the formation of $\mathrm{MoO}_{3}$. However, the reduction upon negative current application results in the regeneration of $\left(\mathrm{H}_{2} \mathrm{MoO}_{3}\right)_{\text {ads }}$ species on the $\mathrm{Pt}$ surface. The electrochemical experiments presented below were designed to give further insight into this question.

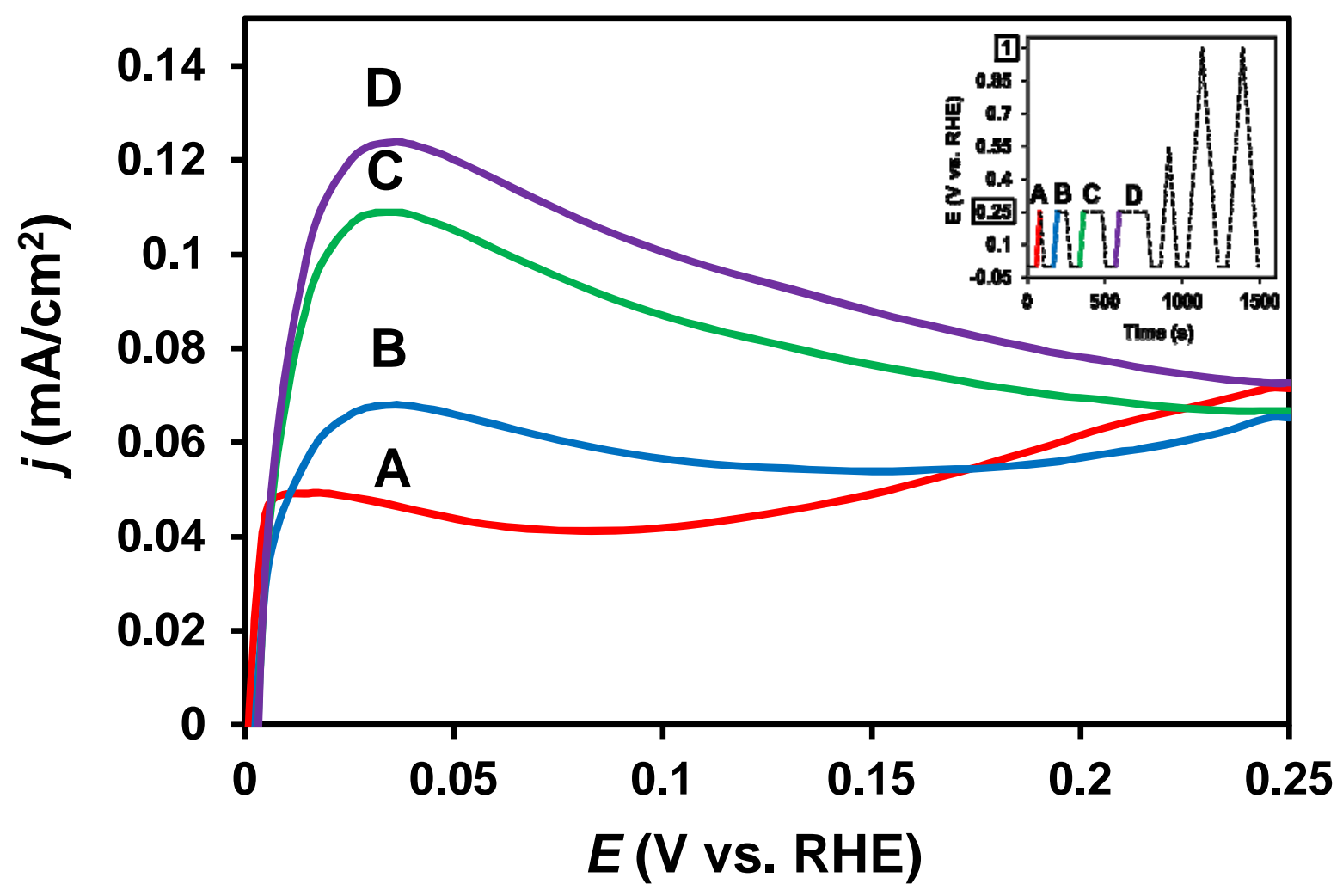

Fig. 2. Argon purged $\mathrm{CO}_{\mathrm{ads}}$ stripping voltammograms obtained on the $\mathrm{Pt} / \mathrm{Ti}_{0.6} \mathrm{Mo}_{0.4} \mathrm{O}_{2}-\mathrm{C}$ catalyst applying the potential program represented by the insert (the colour of the insert solid lines corresponds to the colour of voltammograms shown on the figure). Electrolyte: $0.5 \mathrm{M}$ $\mathrm{H}_{2} \mathrm{SO}_{4}$; scan rate: $10 \mathrm{mV} \mathrm{s}^{-1} ; \mathrm{T}=25^{\circ} \mathrm{C}$.

The fact that $\mathrm{CO}$ oxidation indeed occurs below $250 \mathrm{mV}$ potential on the $\mathrm{Pt} / \mathrm{Ti}_{0.6} \mathrm{Mo}_{0.4} \mathrm{O}_{2}-\mathrm{C}$ catalyst has been verified using electrochemical measurements. A set of Arpurged $\mathrm{CO}_{\mathrm{ads}}$ stripping experiments can be seen in Fig. 2. In this experiment at the end of the Ar purging the working electrode was set to $0 \mathrm{mV}$ and held at this potential for 1 minute. Since at Pt surfaces hydrogen adsorption and evolution take place at $0 \mathrm{mV}$ potential, this treatment results in significant oxidation current during the anodic scan. In this case all Pt 
sites not blocked by the pre-adsorbed $\mathrm{CO}$ are involved in the oxidation of hydrogen. Following this hydrogen exposure a linear potential sweep was measured between 0 and 250 $\mathrm{mV}$. This potential program (i.e. $1 \mathrm{~min}$ at $0 \mathrm{mV}$ and linear sweep) was repeated three times with the difference that before going back to $0 \mathrm{mV}$ the potential was kept at $250 \mathrm{mV}$ for 1, 2 and 3 minutes, respectively. The potential program of this series of measurements can be seen in the insert of Fig. 2.

As emerges from curve $\boldsymbol{A}$ in Fig. 2 there is no significant oxidation current during the first sweep from $0 \mathrm{mV}$ to $250 \mathrm{mV}$. Since adsorbed CO blocks the platinum catalytic sites both adsorption and evolution of hydrogen are hindered. However, from the beginning of the second and during the subsequent cycles an anodic current peak can be observed in this potential region. As emerged from Fig. 2, the longer the holding time at $250 \mathrm{mV}$ is, the higher this anodic peak becomes, which can be correlated to the oxidation of the hydrogen adsorbed on accessible Pt sites. In other words [37,43,52] such experiments reveal the potential at which vacancies are formed in the $\mathrm{CO}_{\mathrm{ads}}$ monolayer. Once $\mathrm{CO}$ desorbs from a fraction of the catalytic sites, $\mathrm{Pt}$ sites become available for the dissociation / electrooxidation of $\mathrm{H}_{2}$ molecules resulting in a steep increase of the current up to the diffusion-limited plateau. These results indicate that oxidation of $\mathrm{CO}$ commences at as low as $250 \mathrm{mV}$ potential and hydrogen adsorption and evolution can take place on the gradually released active sites.

Results of the continuation of the previous measurement are presented in Fig. 3. After the measurements presented in Fig. 2 the anodic limit of the potential scan was increased to $550 \mathrm{mV}$ (above the so called pre-peak potential (ii)) and finally to $1000 \mathrm{mV}$ in order to oxidize the whole amount of adsorbed CO (iii) which remained at the surface during the previous scans (the corresponding potential program can be seen in the insert of Fig. 3).

Fig. 3 shows the influence of the step-by-step increase of the polarization limits on the shape of the voltammograms and on the presence or absence of the pre-oxidation peak. It can be seen that increasing the anodic limit of the polarization to more positive values resulted in an increase of the hydrogen oxidation currents (i). 


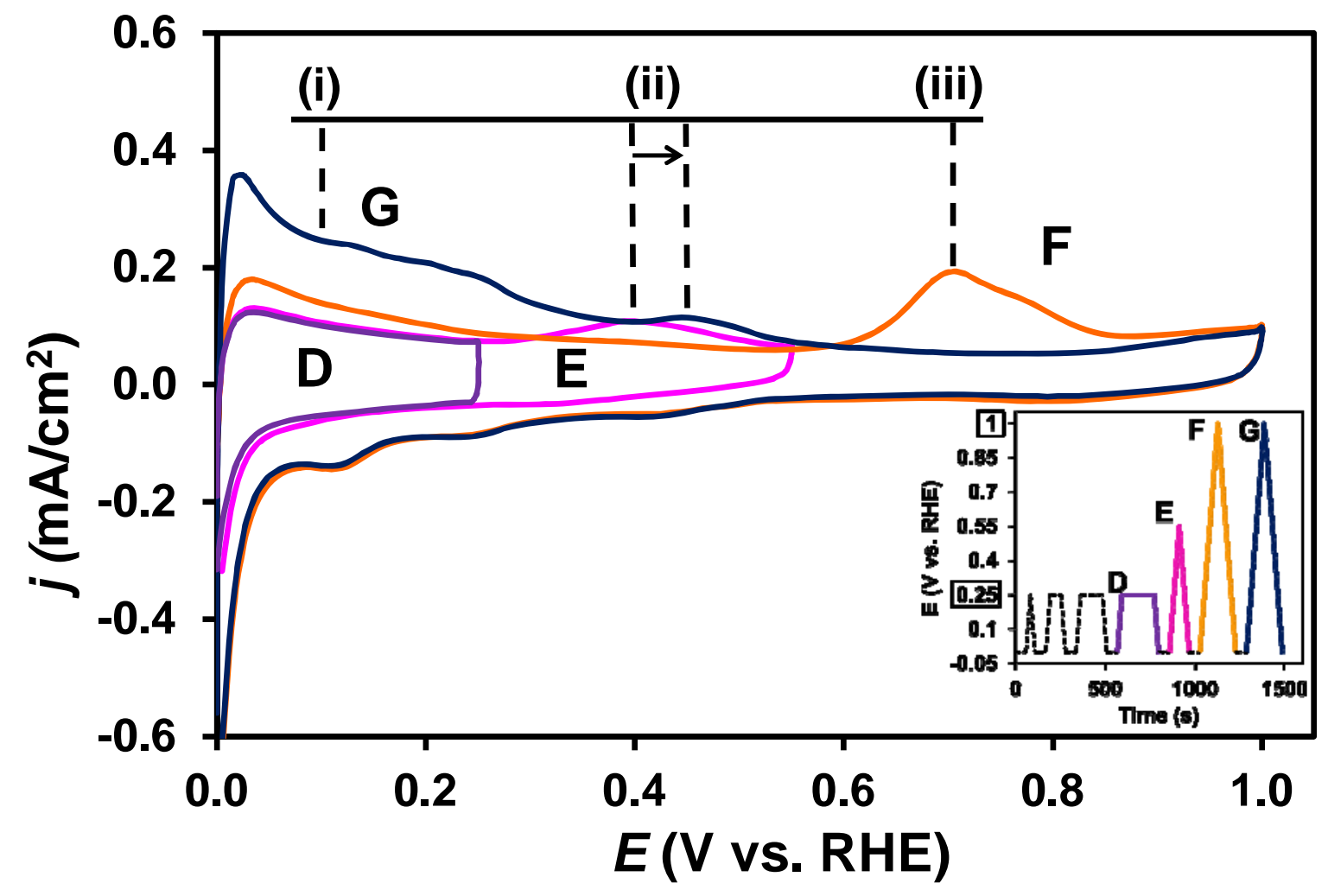

Fig. 3. The $\mathrm{CO}_{\text {ads }}$ stripping voltammograms of the $\mathrm{Pt} / \mathrm{Ti}_{0.6} \mathrm{Mo}_{0.4} \mathrm{O}_{2}-\mathrm{C}$ catalyst obtained after Ar purging using different potential limits. The insert shows the potential program (the colour of the insert lines indicating the potential cycling conditions applied during the measurements corresponds to the colour of voltammograms shown on the figure). Obtained in $0.5 \mathrm{M} \mathrm{H}_{2} \mathrm{SO}_{4}$ at $10 \mathrm{mV} \mathrm{s}^{-1}, \mathrm{~T}=25{ }^{\circ} \mathrm{C}$. Marks of the anodic peaks: oxidation of (i) - hydrogen, (ii) - Mo surface species, and (iii) - strongly bonded CO.

Comparing the curves $\boldsymbol{D}$ and $\boldsymbol{E}$ in Fig. 3 it can be seen that after holding the potential at $250 \mathrm{mV}$ for 3 minutes there is no further change in the shape of the voltammetric curves in the hydrogen oxidation region (i) (up to $250 \mathrm{mV}$ curve $\boldsymbol{D}$ practically coincides with curve $\boldsymbol{E}$ ). From this result it can be concluded that during this time the whole amount of weakly adsorbed CO, which can be oxidized below $250 \mathrm{mV}$, has been eliminated from the catalyst surface. After increasing the potential limit of the polarization up to $550 \mathrm{mV}$ a characteristic "pre-peak" (ii) was observed in the first cycle around $400 \mathrm{mV}$ (see curve $\boldsymbol{E}$ in Fig. 3). As it was mentioned above, the presence of the pre-oxidation peak can be associated with two processes: partial oxidation of weakly adsorbed $\mathrm{CO}$ and oxidation of Mo surface species, which correspond to the peaks (ii') and (ii) in Fig. 1b, respectively.

This pre-oxidation peak (ii) completely disappears in the next cycle (see curve $\boldsymbol{F}$ in Fig. 3), however it has been re-emerged when the electrode was polarized to $1000 \mathrm{mV}$ (see 
curve $G$ in Fig. 3), where the whole amount of adsorbed $\mathrm{CO}$ was oxidized and Pt surface has been completely recovered, resulted in pronounced increase of the hydrogen oxidation peak (i).
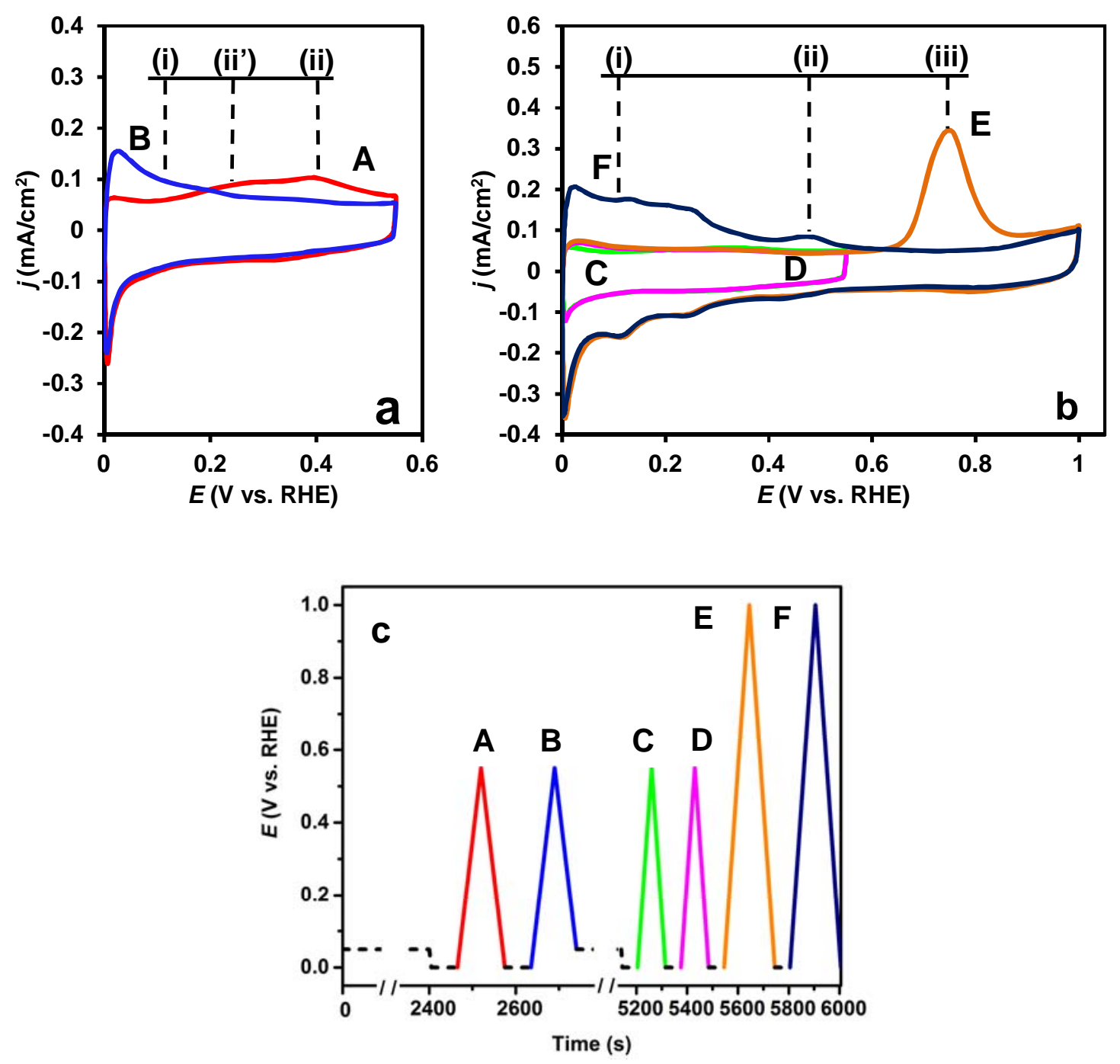

Fig. 4. The $\mathrm{CO}_{\text {ads }}$ stripping voltammograms of the $\mathrm{Pt} / \mathrm{Ti}_{0.6} \mathrm{Mo}_{0.4} \mathrm{O}_{2}-\mathrm{C}$ catalyst obtained after Ar purging using different potential limits $(\mathrm{a}, \mathrm{b})$; (c) shows the potential program (the colour of the insert lines indicating the potential cycling conditions applied during the measurements corresponds to the colour of voltammograms shown on the figure). For further details see the text. Obtained in $0.5 \mathrm{M} \mathrm{H}_{2} \mathrm{SO}_{4}$ at $10 \mathrm{mV} \mathrm{s}^{-1}, \mathrm{~T}=25{ }^{\circ} \mathrm{C}$. Marks of the anodic peaks: oxidation of (i) - hydrogen, (ii') - weakly bonded CO, (ii) - Mo surface species, and (iii) - strongly bonded CO.

The following experiment gives further insight into the nature of the pre-peak and its relation to the $\mathrm{CO}$ oxidation process on Mo-containing catalysts. Saturation of the catalyst 
surface with $\mathrm{CO}_{\mathrm{ads}}$ and purging the $\mathrm{CO}$ from the solution were carried out the same way as in the preceding experiments; then two cyclic voltammograms were recorded after holding the potential of the electrode at $0 \mathrm{mV}$ for $1 \mathrm{~min}$ (curves $\boldsymbol{A}$ and $\boldsymbol{B}$ in Fig. 4a).

The shape of the first voltammogram (curve $\boldsymbol{A}$ in Fig 4a) recorded between 0-550 $\mathrm{mV}$ is similar to that in Fig. 1b. Comparison with curve $\boldsymbol{E}$ in Fig. 3 reveals that in addition to the feature around $400 \mathrm{mV}$ (ii), in this case a clear peak (or hump) appears below $300 \mathrm{mV}$ potential, which can be assigned to the electrooxidation of weakly bounded CO (ii') (these species were removed during the steady polarization at $250 \mathrm{mV}$ in the experiment represented by Figs. 2-3). Between 0 and $550 \mathrm{mV}$ the anodic part of the second cycle (curve $\boldsymbol{B}$, Fig. 4a) is identical with curve $\boldsymbol{F}$ in Fig. 3; there is only characteristic current signal (i) of the oxidation of the small amount of hydrogen (which could be evolved or adsorbed on the active sites released from the weakly bounded $\mathrm{CO}$ ).

After recording these two voltammograms presented in Fig 4a the CO-saturation step was repeated; first $\mathrm{CO}$ and then Ar was bubbled into the solution for 20-20 min, while holding the potential at $50 \mathrm{mV}$ (the applied potential cycling conditions are shown on Fig. 4c). In spite of the exactly same procedure, the first and the second voltammograms (curves $\boldsymbol{C}$ and $\boldsymbol{D}$, in Fig $4 \mathrm{~b}$ ) obtained after the second CO saturation significantly differ from curves $\boldsymbol{A}$ and $\boldsymbol{B}$ in Fig 4a. All characteristic peaks of the voltammograms represented by curves $\boldsymbol{A}$ and $\boldsymbol{B}$ (namely, the pre-oxidation peak of the weakly bounded CO (ii') and the hydrogen oxidation peak in the second cycle (i)) are missing from curves $C$ and $D$ in Fig $4 b$. It means that the catalytic surface lost its capability to oxidise $\mathrm{CO}$ at low potential values and the active sites are blocked by adsorbed CO. At the same time the Mo redox peak pair around $400 \mathrm{mV}$ (ii) also disappeared, which indicate that $\mathrm{CO}$ tolerance can be in close connection with these features.

However, in this case the loss of activity is not an irreversible process. After oxidation of the strongly adsorbed CO (iii) with a simple potential scan to $1000 \mathrm{mV}$ (see curve $\boldsymbol{E}$ in Fig 4b) the hydrogen oxidation peak (i) and the Mo redox peak pair (ii) could be recovered (curve $\boldsymbol{F}$ in Fig 4 b), as well as the low potential CO oxidising capability of the surface.

The co-catalytic effect of Mo on the oxidation of adsorbed $\mathrm{CO}$ at low potentials can be explained by an oxygen spillover effect (see Eq. 1) requiring $\mathrm{OH}$ groups from Mo species with oxidation state lower than $6+$. This process is only working for $\mathrm{CO}$ in the weakly adsorbed state, while at high potentials (above $550 \mathrm{mV}$ ) the oxides of Pt begin to play a principal role in the electrooxidation of strongly bonded $\mathrm{CO}$. 
Moreover, it has been observed that, when the catalysts are submitted to potentials above $400 \mathrm{mV}$, the Mo species become oxidized and simultaneously their activity is lost. These results suggest that this extensive oxidation hinders the oxygen spillover capability of the Mo species in close vicinity to Pt particles, leading to the loss of the CO oxidation activity at low potentials. In order to restore this activity, reduction of the mentioned Mo species is needed, which requires an abundant source of hydrogen in the form of hydrogen spillover [53] and/or charge transfer from Pt particles released from CO [54]. It is supposed that the hydrogen replacing the weakly adsorbed $\mathrm{CO}$ (evidenced by the hydrogen oxidation peak (i) in Fig. $4 \mathrm{a}$ (curve $B$ )) is either not reactive enough or not abundant enough to restore the reduced state of Mo species.

The existence of the hydrogen spillover process needed for reactivation of the catalyst is indicated by our XPS measurements. In Fig. 5 Mo $3 \mathrm{~d}$ core level spectra are shown for a $\mathrm{Pt} / \mathrm{Ti}_{0.6} \mathrm{Mo}_{0.4} \mathrm{O}_{2}-\mathrm{C}$ catalyst in the as received state (after the final annealing of the synthesis, the sample was stored in air for a while) and after exposure to $300 \mathrm{mbar}_{2}$ in the preparation chamber of the electron spectrometer for $1 \mathrm{~h}$ at room temperature. These spectra are compared to that obtained for a Pt-free $\mathrm{Ti}_{0.6} \mathrm{Mo}_{0.4} \mathrm{O}_{2}$-C support after a hydrogen exposure with the same conditions as in the case of the Pt-containing electrocatalyst.

As it was described in our earlier works [40,41], air exposure of the composite support results in oxidation of surface Mo species to the $\mathrm{Mo}^{6+}$ oxidation state, which is reflected by the strong spin-orbit doublet around 232.4 and $235.5 \mathrm{eV}$ [55]. In the spectrum of the as received $\mathrm{Pt} / \mathrm{Ti}_{0.6} \mathrm{Mo}_{0.4} \mathrm{O}_{2}-\mathrm{C}$ catalyst weak contributions from $\mathrm{Mo}^{5+}$ and $\mathrm{Mo}^{4+}$ arise as a doublet at 231.0 and $234.1 \mathrm{eV}\left(\mathrm{Mo}^{5+},[55]\right)$ and as a broad band with leading peak at $230.0 \mathrm{eV}\left(\mathrm{Mo}^{4+}\right.$, $[56,57])$, respectively. In this work, the Mo $3 \mathrm{~d}$ core level spectrum from $\mathrm{Mo}^{4+}$ species was modelled by a complex line shape consisting of a combination of a narrower and a broad spinorbit splitted doublet representing differently screened final states, with the most intense contribution between 229-230 eV [56,57]. In spite of the air exposure of the as received samples, the Pt content of the composite supported electrocatalyst is predominantly metallic (data not shown).

The room temperature hydrogen exposure almost completely reduced the Pt. Moreover, in Fig. 5 considerable reduction of the Mo content of the $\mathrm{Pt} / \mathrm{Ti}_{0.6} \mathrm{Mo}_{0.4} \mathrm{O}_{2}-\mathrm{C}$ sample is evident: the intensity from both the $\mathrm{Mo}^{5+}$ and $\mathrm{Mo}^{4+}$ contributions significantly increased at the expense of the $\mathrm{Mo}^{6+}$ signal (all Mo 3d spectra were satisfactorily fitted with the mentioned $\mathrm{Mo}^{6+}, \mathrm{Mo}^{5+}$ and $\mathrm{Mo}^{4+}$ contributions). On the contrary, only a marginal Mo reduction occurs in the Pt-free composite support material. As hydrogen is dissociatively adsorbed on Pt, our 
observation demonstrates that the Pt particles act as sources for reactive hydrogen species, which easily reduce even the heavily oxidized Mo species in the vicinity of the Pt. In the lack of Pt, such spillover induced reduction is absent. It may be worth to note that the Ti content of the composite support cannot be reduced this way: the Ti $2 \mathrm{p}$ spectra of either the $\mathrm{Ti}_{0.6} \mathrm{Mo}_{0.4} \mathrm{O}_{2}-\mathrm{C}$ support or the $\mathrm{Pt} / \mathrm{Ti}_{0.6} \mathrm{Mo}_{0.4} \mathrm{O}_{2}-\mathrm{C}$ electrocatalyst are essentially identical both in the as received (air exposed) or reduced $\left(\mathrm{H}_{2}\right.$ exposed) state.

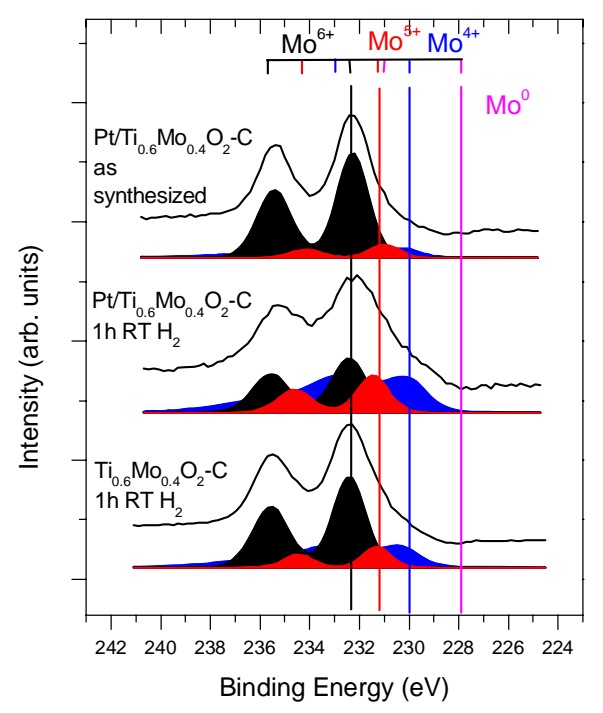

Fig. 5. Effect of $300 \mathrm{mbar}_{2}$ exposure for $1 \mathrm{~h}$ at room temperature on the Mo $3 \mathrm{~d}$ core level spectra of Pt-loaded and Pt-free $\mathrm{Ti}_{0.6} \mathrm{Mo}_{0.4} \mathrm{O}_{2}-\mathrm{C}$ composites compared to that of a $\mathrm{Pt} / \mathrm{Ti}_{0.6} \mathrm{Mo}_{0.4} \mathrm{O}_{2}-\mathrm{C}$ catalyst in the "as received" state. Hydrogen treatments were carried out in the preparation chamber of the electron spectrometer, thus air exposure was eliminated during the experiments.

The above electrochemical observations confirm that the key feature of the CO tolerance of the Mo-containing Pt-based electrocatalysts is the presence of partially oxidized Mo species, while the XPS data proved that these species have to be located in atomic closeness to Pt. These species provide oxidizing agents for oxidation of $\mathrm{CO}$ in a process described in Eq. 1 above. They are relatively stable under the conditions of the electrochemical experiments, unless the applied potential exceeds $350 \mathrm{mV}$. Under higher potential, they are oxidized into stable, non-reactive Mo species (presumably into $\mathrm{Mo}^{6+}$ ), which cannot be reduced by a cathodic scan unless the surface is polarized to potentials high enough for oxidation of the strongly bound CO species. As it was mentioned above, it can be 
assumed that hydrogen replacing the weakly adsorbed CO is not suitable to accomplish this regenerative process. Another possibility may be that some $\mathrm{CO}$ oxidation products block the inactivated site and prevent its reduction, until they are removed together with the strongly bound $\mathrm{CO}$. The extensive literature on $\mathrm{CO}$ electrooxidation on Pt suggests that carboxyl groups may be candidates for this role: both in situ Fourier-transform infrared spectroscopy (FTIR) [58,59] and electrochemical quartz crystal microbalance (EQCM) [60,61] experiments as well as ab initio calculations [62] indicate their formation and demonstrate their stability up to at least $0.55 \mathrm{~V}$. Carbonate species arising from surface reaction of $\mathrm{CO}_{2}$ with water adsorbed on $\mathrm{Pt}$ (where $\mathrm{H}_{2} \mathrm{O}$ acts as a source of oxygen for the oxidation reaction $[58,63]$ ) are reported to be observable above $0.8 \mathrm{~V}$. However, it has been mentioned, that the concentration of $\mathrm{CO}_{3}{ }^{2-}$ or $\mathrm{HCO}_{3}{ }^{-}$is very low in the strong acid electrolyte. Carbonyl species like the formyl group are less likely candidates for this site blocking role, as such groups are usually observed upon electrooxidation of methanol or formic acid in acid solutions [64]. Nevertheless, further discussion of the possible intermediates formed during the $\mathrm{CO}$ electrooxidation is out of the scope of this work and will not be further considered.

Qualitatively very similar findings to those described above were earlier reported by Papakonstantinou et al. [25] on carbon supported $\mathrm{Pt}_{4} \mathrm{Mo}$ alloy catalysts. They argued that since the presence of $\mathrm{CO}$ on the surface blocks the adsorption Pt sites, the reduction of the $\mathrm{Mo}^{\mathrm{x}+}$ species on the Pt surface are prevented. As a consequence, in the presence of $\mathrm{CO}$, negative current application does not result in the reactivation of the catalytically active sites. Moreover, much more pronounced Mo redox process involving protons and electrons can be observed for the Mo sites located in a close contact with Pt $[18,26,53,65,66]$. Thus we believe that the hindered reduction of highly oxidized Mo species in the presence of strongly bound $\mathrm{CO}$ is a general feature of the Mo-Pt catalyst system, regardless if Mo is present in PtMo alloy form or Mo oxide is used as a constituent of the support.

In order to demonstrate the exceptional low potential, where the $\mathrm{CO}$ oxidation commences, experiments presented in Fig. 2 were repeated extending the investigation to commercial PtRu/C and Pt/C catalyst samples. Fig. 6a shows the results of this experiment with $250 \mathrm{mV}$ upper potential limit, while in Fig. $6 \mathrm{~b}$ this potential limit was increased to 350 $\mathrm{mV}$. For the sake of visibility only the first and the fourth voltammograms are depicted.

Upon using of the $\mathrm{Pt} / \mathrm{Ti}_{0.6} \mathrm{Mo}_{0.4} \mathrm{O}_{2}-\mathrm{C}$ catalyst (see Fig. 6a) in the first anodic scan no oxidation current can be observed, but during the fourth anodic scan immediately from the beginning high peak of oxidation current was detected. In contrast, for the commercial $\mathrm{PtRu} / \mathrm{C}$ and $\mathrm{Pt} / \mathrm{C}$ catalysts the current density values are the same in the first and the fourth scans. For 
the Mo-containing catalyst the oxidation current of the in-situ-developed- $\mathrm{H}_{2}$ is higher in the case of the experiment limited to $350 \mathrm{mV}$ due to the larger $\mathrm{CO}$ free platinum surface caused by the higher potential value of the sweep, and a small activity already appears for the PtRu/C catalyst as well, see on Fig. 6b. However in case of Pt/C no similar effect could be observed.
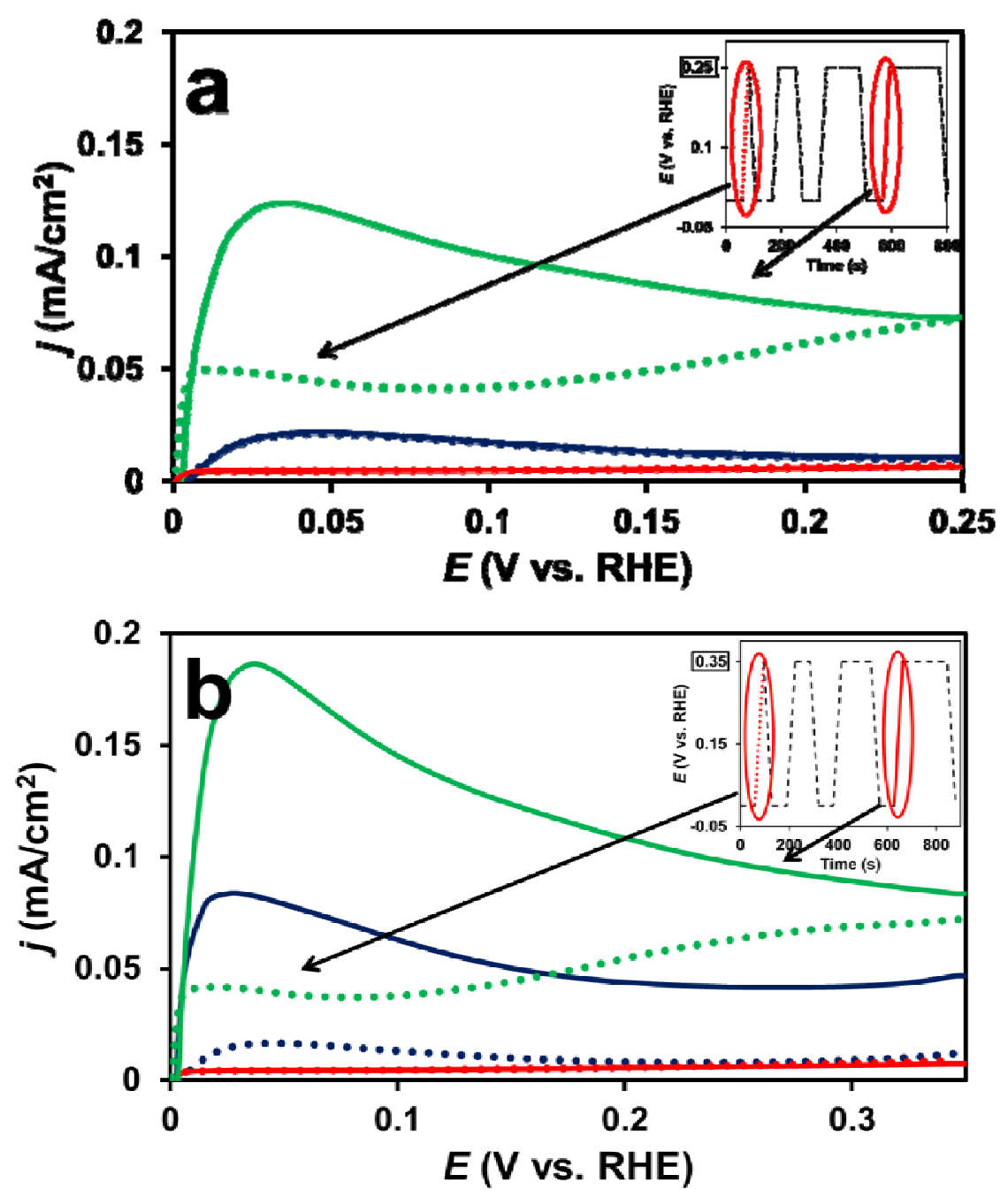

Fig. 6. Argon purged $\mathrm{CO}_{\mathrm{ads}}$ stripping voltammograms obtained on the $\mathrm{Pt} / \mathrm{Ti}_{0.6} \mathrm{Mo}_{0.4} \mathrm{O}_{2}-\mathrm{C}$ (green line), PtRu/C (blue line) and Pt/C (red line) catalysts using different potential limits (A: $250 \mathrm{mV}$; B: $350 \mathrm{mV}$ ) of the hydrogen potential range. The insert shows the potential program (the arrow indicates the potential cycling conditions applied during the measurements). Voltammograms were recorded after a potential stop at $0 \mathrm{~V}$ for 1 min (dotted lines) and after sequential potential cycling steps according to the insert (solid lines). Obtained in $0.5 \mathrm{M}$ $\mathrm{H}_{2} \mathrm{SO}_{4}$ at $10 \mathrm{mV} \mathrm{s}^{-1}, \mathrm{~T}=25{ }^{\circ} \mathrm{C}$.

Complex character of the pre-peak in the case of the $\mathrm{Pt} / \mathrm{Ti}_{0.6} \mathrm{Mo}_{0.4} \mathrm{O}_{2}-\mathrm{C}$ catalyst is demonstrated by Fig. 7. Anodic scans of four different modified $\mathrm{CO}_{\mathrm{ads}}$ stripping voltammetry 
measurements are represented between $0 \mathrm{mV}$ and $550 \mathrm{mV}$. The purpose of these measurements was to provide information about the correlation between the CO oxidation pre-peak and the hydrogen oxidation activity. In this experiment each measurement was carried out on freshly prepared electrode, thus each was preceded by the $\mathrm{CO}$ saturation and $\mathrm{Ar}$ purging.

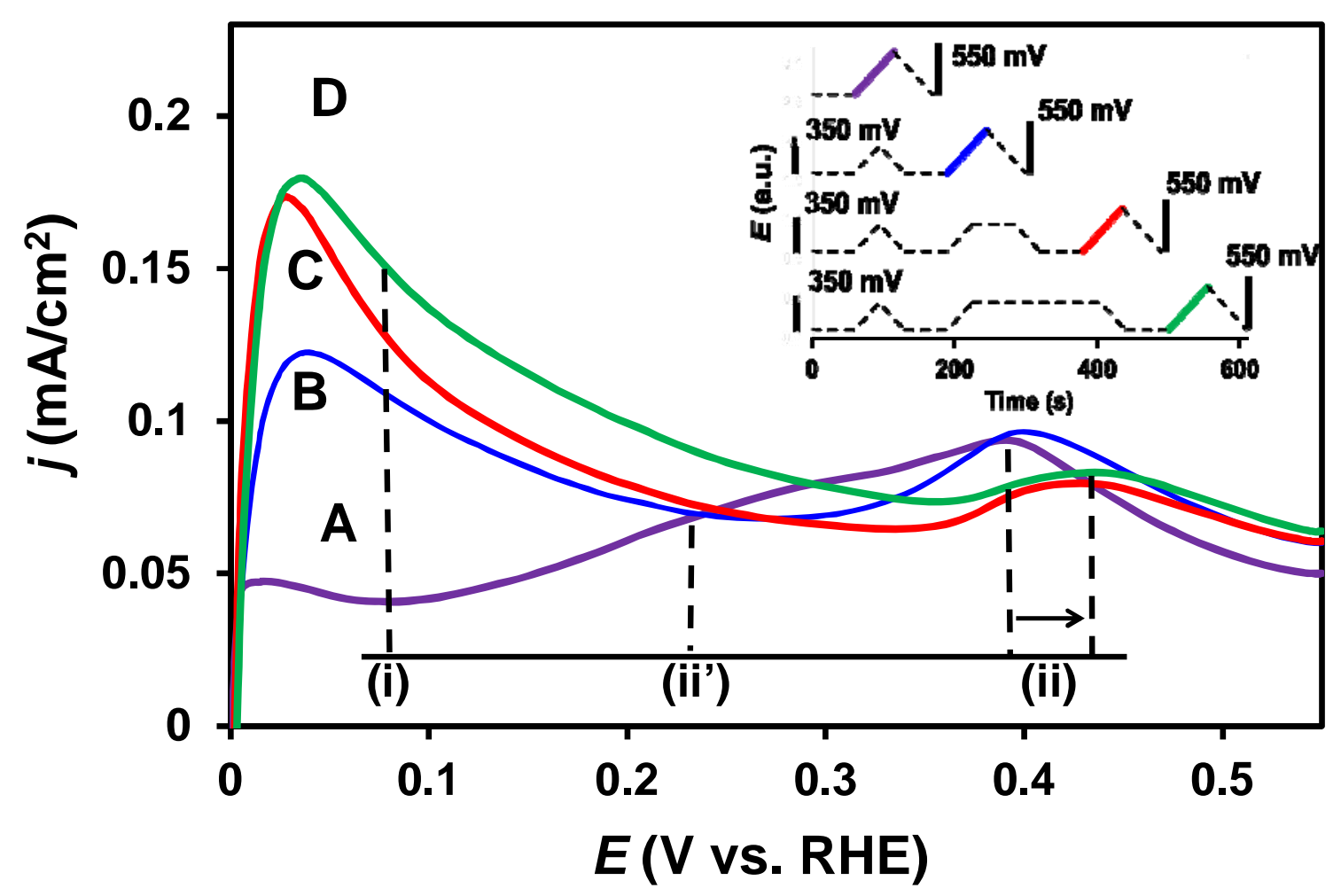

Fig. 7. Argon purged $\mathrm{CO}_{\mathrm{ads}}$ stripping voltammograms obtained on the $\mathrm{Pt} / \mathrm{Ti}_{0.6} \mathrm{Mo}_{0.4} \mathrm{O}_{2}-\mathrm{C}$ catalyst applying the potential program represented by the insert (the colour of the insert solid lines corresponds to the colour of voltammograms shown on the figure). Electrolyte: $0.5 \mathrm{M}$ $\mathrm{H}_{2} \mathrm{SO}_{4}$; scan rate: $10 \mathrm{mV} \mathrm{s}^{-1} ; \mathrm{T}=25^{\circ} \mathrm{C}$. Marks of the peaks: oxidation of (i) - hydrogen, (ii') weakly bonded CO, and (ii) - Mo surface species.

At the first measurement (after the gas bubbling process) the working electrode was set to $0 \mathrm{mV}$ for 1 minute then polarized to $550 \mathrm{mV}$ and back to $0 \mathrm{mV}$ (curve $\boldsymbol{A}$ in Fig. 7). In the second the working electrode was set to $0 \mathrm{mV}$ for 1 minute then polarized to $350 \mathrm{mV}$ and immediately back to $0 \mathrm{mV}$. It was held again for 1 minute at $0 \mathrm{mV}$ and then polarized to 550 $\mathrm{mV}$ and back to $0 \mathrm{mV}$ (curve $\boldsymbol{B}$ in Fig. 7) as in the previous case. In the subsequent experiments the procedure was the same with the difference that the working electrode was 
held at $350 \mathrm{mV}$ for 1 or 3 minutes (curves $\boldsymbol{C}$ and $\boldsymbol{D}$ in Fig. 7). The potential program is shown on Fig. 7 as an insert.

At the first anodic scan (curve $\boldsymbol{A}$ in Fig. 7) we can see a sweep which has not been preceded by any other scans therefore there is no hydrogen oxidation current (i) and the socalled pre-peak consisting of oxidation of both weakly bonded CO (ii') and Mo surface species (ii) appears. The weakly bonded CO oxidation peak (ii') observed on curve $\boldsymbol{A}$ is larger than the following ones and starts at around $100 \mathrm{mV}$. The following scans were all recorded after some polarization of the electrode between $0 \mathrm{mV}$ and $350 \mathrm{mV}$ (see the applied potential program on the figure). It can be seen that the increase of the prolongation of the treatment of the catalyst before the recorded scan results in an increase of the oxidation current of the in situ developed hydrogen (i), disappearance of the $\mathrm{CO}$ oxidation related contributions (ii') and some shift of the Mo oxidation peak (ii) toward more positive potentials. In Ref. [54] it has been demonstrated that the Mo redox couple is affected by the presence or absence of $\mathrm{CO}$ adsorbed on Pt. After CO electrooxidation similar shift of the Mo oxidation peak toward more positive potentials was observed.

The results of the modified $\mathrm{H}_{2}$-purged $\mathrm{CO}_{\mathrm{ads}}$ stripping voltammetry measurement followed by a HOR measurement on RDE provide further details about the CO tolerance and catalytic activity of the compared catalysts (Fig. 8). Both the Mo-containing composite supported and the commercially available $\mathrm{Pt} / \mathrm{C}$ and $\mathrm{PtRu} / \mathrm{C}$ catalysts were tested this way.

We can see that there is no catalytic activity on both the $\mathrm{Pt} / \mathrm{C}$ and the $\mathrm{PtRu} / \mathrm{C}$ catalysts in HOR if the previously CO covered electrode was polarized only to $250 \mathrm{mV}$ in comparison with the Mo-containing composite supported catalyst which shows significant activity (see Fig. 8a). On Fig. 8b with $350 \mathrm{mV}$ upper potential limit for polarization it seems that the $\mathrm{Pt} / \mathrm{C}$ is not active, the activity of $\mathrm{PtRu} / \mathrm{C}$ catalyst is increased but it is still below that of the $\mathrm{Pt} / \mathrm{Ti}_{0.6} \mathrm{Mo}_{0.4} \mathrm{O}_{2}-\mathrm{C}$ catalyst. On Fig. $8 \mathrm{c}$ and $8 \mathrm{~d}$ the $\mathrm{PtRu} / \mathrm{C}$ catalyst shows more activity than the $\mathrm{Pt} / \mathrm{Ti}_{0.6} \mathrm{Mo}_{0.4} \mathrm{O}_{2}-\mathrm{C}$ and the $\mathrm{Pt} / \mathrm{C}$ shows improvement too. On Fig. 8e, which shows curves recorded after removing $\mathrm{CO}$ from the whole active surface by polarizing the working electrode to $1000 \mathrm{mV}$ and thus oxidizing the $\mathrm{CO}$, it seems that the most active catalyst is the $\mathrm{Pt} / \mathrm{C}$, the second one is the $\mathrm{PtRu} / \mathrm{C}$, and the third one is the $\mathrm{Pt} / \mathrm{Ti}_{0.6} \mathrm{Mo}_{0.4} \mathrm{O}_{2}-\mathrm{C}$. 

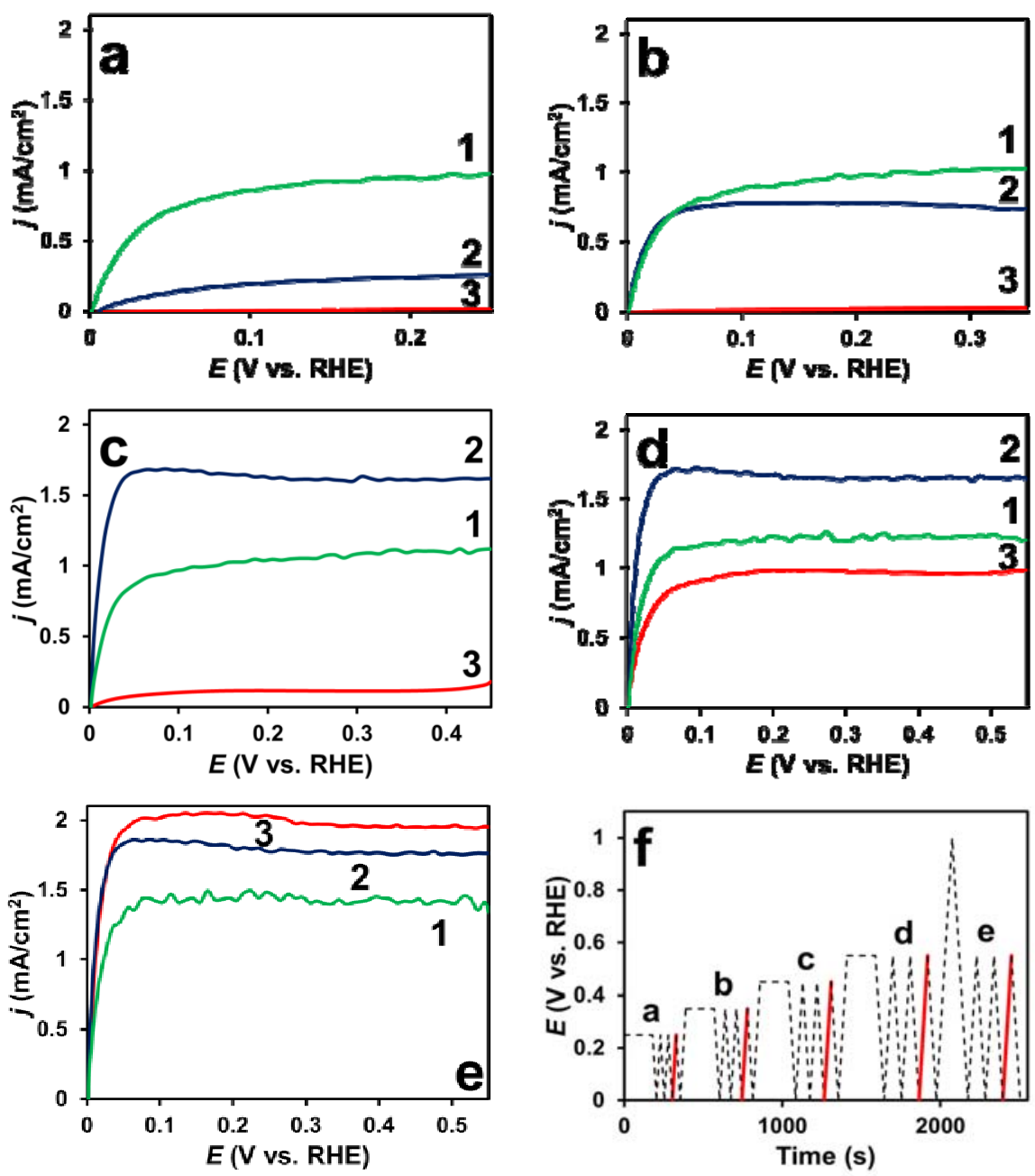

Fig. 8. Linear potential sweeps (a-e) of the $\mathrm{Pt} / \mathrm{Ti}_{0.6} \mathrm{Mo}_{0.4} \mathrm{O}_{2}-\mathrm{C}$ (1 green line), $\mathrm{PtRu} / \mathrm{C}(2$ blue line) and $\mathrm{Pt} / \mathrm{C}$ (3 red line) catalyst samples obtained in $\mathrm{H}_{2}$ saturated $0.5 \mathrm{M} \mathrm{H}_{2} \mathrm{SO}_{4}$ at a rotating disc electrode (at 625 revolutions/min). Before the measurements the electrodes were polarized at $0 \mathrm{mV}$ for 30 minutes in $\mathrm{CO}$-saturated electrolyte (CO adsorption) and exposed to the potential program depicted in figure (f) in $\mathrm{H}_{2}$-saturated electrolyte. Sweep rate: $10 \mathrm{mV} \mathrm{s}$.

\section{Conclusions}

The peculiarities of novel 20 wt. $\%$ Pt electrocatalyst supported on $\mathrm{Ti}_{0.6} \mathrm{Mo}_{0.4} \mathrm{O}_{2}-\mathrm{C}$ composite material in low-potential CO oxidation reaction were investigated. From the results of the electrochemical measurements it can be concluded that:

(i) oxidation of $\mathrm{CO}$ takes place at exceptionally low potential values at the

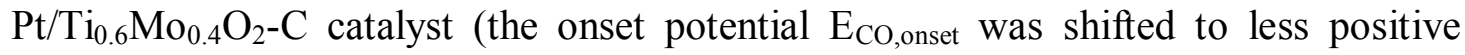
potentials by 530 and $150 \mathrm{mV}$ comparing to the $\mathrm{Pt} / \mathrm{C}$ and $\mathrm{PtRu} / \mathrm{C}$, respectively); 
(ii) the so-called "pre-peak" on the voltammograms obtained during the $\mathrm{CO}_{\text {ads }}$ stripping measurements, consist of at least two oxidation reaction: partial oxidation of weakly adsorbed CO and oxidation of Mo surface species;

(iii) when the weakly bounded $\mathrm{CO}$ is oxidized, some hydrogen adsorption can take place on the released surface, although this amount is much smaller than in the case of a CO-free Pt surface;

(iv)the $\mathrm{Pt} / \mathrm{Ti}_{0.6} \mathrm{Mo}_{0.4} \mathrm{O}_{2}-\mathrm{C}$ catalyst loses its activity in the low-potential $\mathrm{CO}$ oxidation reaction when Mo becomes oxidized (above ca. $400 \mathrm{mV}$ );

(v) in the presence of CO-free platinum surface oxidized Mo can be re-reduced and the activity in the low-potential CO oxidation reaction can be restored; nevertheless, rereduction of oxidized species formed above $400 \mathrm{mV}$ is strongly hindered when adsorbed $\mathrm{CO}$ species are still present. Note that $\mathrm{CO}_{\mathrm{ads}}$ species can be completely removed only above $550 \mathrm{mV}$.

These results suggest that only CO adsorbed on specific Pt sites (weakly bounded CO), where Pt and Mo atoms are in atomic closeness, can be oxidised below $400 \mathrm{mV}$ potential. Clear correlation between the so-called "pre-peak", the molybdenum redox phenomenon and the $\mathrm{CO}$ tolerance of the $20 \mathrm{wt} \% \mathrm{Pt} / \mathrm{Ti}_{0.6} \mathrm{Mo}_{0.4} \mathrm{O}_{2}-\mathrm{C}$ system was established. Accordingly, presence of Mo species in lower oxidation state than $6+$ is supposed to have crucial role in $\mathrm{CO}$ oxidation. Better performance of the $\mathrm{Pt} / \mathrm{Ti}_{0.6} \mathrm{Mo}_{0.4} \mathrm{O}_{2}-\mathrm{C}$ electrocatalysts compared to the reference $\mathrm{Pt} / \mathrm{C}$ and state-of-art $\mathrm{CO}$-tolerant $\mathrm{PtRu} / \mathrm{C}$ catalysts was also demonstrated.

\section{Acknowledgements}

The research within project No. VEKOP-2.3.2-16-2017-00013 was supported by the European Union and the State of Hungary, co-financed by the European Regional Development Fund. Financial support by the OTKA-project [grant number K112034 (István Bakos)] is greatly acknowledged.

\section{References}

[1] Meier JC, Galeano C, Katsounaros I, Topalov AA, Kostka A, Schuüth F, Mayrhofer KJJ (2012) Degradation Mechanisms of Pt/C Fuel Cell Catalysts under Simulated Start-Stop Conditions. ACS Catalysis 2(5):832-843 
[2] Huang SY, Ganesan P, Popov BN (2009) Development of a Titanium Dioxide-Supported Platinum Catalyst with Ultrahigh Stability for Polymer Electrolyte Membrane Fuel Cell Applications. J Am Chem Soc 131:13898-13899

[3] Lv Q, Yin M, Zhao X, Li C, Liu C, Xing W (2012) Promotion effect of $\mathrm{TiO}_{2}$ on catalytic activity and stability of Pt catalyst for electrooxidation of methanol. J Power Sources 218:9399

[4] Huang J, Zang J, Zhao Y, Dong L, Wang Y (2014) One-step synthesis of nanocrystalline $\mathrm{TiO}_{2}$-coated carbon nanotube support for Pt electrocatalyst in direct methanol fuel cell. Mater Lett 137:335-338

[5] Vogel W, Timperman L, Alonso-Vante N (2010) Probing metal substrate interaction of Pt nanoparticles: Structural XRD analysis and oxygen reduction reaction. Appl Catal A: General 377:167-173

[6] Liu X, Chen J, Liu G, Zhang L, Zhang H, Yi B (2010) Enhanced long-term durability of proton exchange membrane fuel cell cathode by employing $\mathrm{Pt} / \mathrm{TiO}_{2} / \mathrm{C}$ catalysts. $\mathrm{J}$ Power Sources 195:4098-4103

[7] von Kraemer S, Wikander K, Lindbergh G, Lundblad A, Palmqvist AEC (2008) Evaluation of $\mathrm{TiO}_{2}$ as catalyst support in $\mathrm{Pt}-\mathrm{TiO}_{2} / \mathrm{C}$ composite cathodes for the proton exchange membrane fuel cell. J Power Sources 180:185-190

[8] Bauer A, Song C, Ignaszak A, Hui R, Zhang J, Chevallier L, Jones D, Roziére J (2010) Improved stability of mesoporous carbon fuel cell catalyst support through incorporation of $\mathrm{TiO}_{2}$. Electrochim Acta 55:8365-8370

[9] Wang D, Subban CV, Wang H, Rus E, DiSalvo FJ, Abruña HD (2010) Highly Stable and CO-Tolerant $\mathrm{Pt} / \mathrm{Ti}_{0.7} \mathrm{~W}_{0.3} \mathrm{O}_{2}$ Electrocatalyst for Proton-Exchange Membrane Fuel Cells. J Am Chem Soc 132:10218-10220

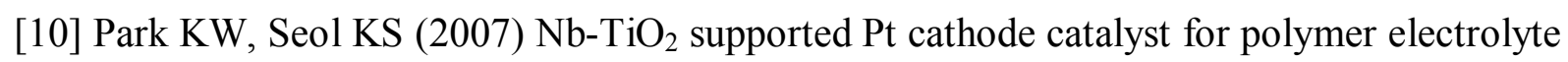
membrane fuel cells. Electrochem Commun 9:2256-2260

[11] Huang SY, Ganesan P, Popov BN (2010) Electrocatalytic activity and stability of niobium-doped titanium oxide supported platinum catalyst for polymer electrolyte membrane fuel cells. Appl Catal B: Environ 96:224-231

[12] Kumar A, Ramani V (2013) $\mathrm{Ta}_{0.3} \mathrm{Ti}_{0.7} \mathrm{O}_{2}$ Electrocatalyst Supports Exhibit Exceptional Electrochemical Stability. J Electrochem Soc 160:F1207-F1215 
[13] Subban CV, Zhou Q, Hu A, Moylan TE, Wagner FT, DiSalvo FJ (2010) Sol-Gel Synthesis, Electrochemical Characterization, and Stability Testing of $\mathrm{Ti}_{0.7} \mathrm{~W}_{0.3} \mathrm{O}_{2}$ Nanoparticles for Catalyst Support Applications in Proton-Exchange Membrane Fuel Cells. J Am Chem Soc 132:17531-17536

[14] Pereira LGS, dos Santos FR, Pereira ME, Paganin VA, Ticianelli EA (2006) CO tolerance effects of tungsten-based PEMFC anodes. Electrochim Acta 51:4061-4066

[15] Maillard F, Peyrelade E, Soldo-Olivier Y, Chatenet M, Chaînet E, Faure R (2007) Is carbon-supported Pt- $\mathrm{WO}_{\mathrm{x}}$ composite a CO-tolerant material?" Electrochim Acta 52:19581967

[16] Ioroi T, Fujiwara N, Siroma Z, Yasuda K, Miyazaki Y (2002) Platinum and molybdenum oxide deposited carbon electrocatalyst for oxidation of hydrogen containing carbon monoxide. Electrochem Commun 4:442-446

[17] Santiago EI, Batista MS, Assaf EM, Ticianelli EA (2004) Mechanism of CO Tolerance on Molybdenum-Based Electrocatalysts for PEMFC. J Electrochem Soc 151(7):A944-A949

[18] Santiago EI, Camara GA, Ticianelli EA (2003) CO tolerance on PtMo/C electrocatalysts prepared by the formic acid method. Electrochim Acta 48:3527-3534

[19] Elezović NR, Gajić-Krstajić LjM, Vračar LjM, Krstajić NV (2010) Effect of chemisorbed $\mathrm{CO}$ on $\mathrm{MoO}_{\mathrm{x}}-\mathrm{Pt} / \mathrm{C}$ electrode on the kinetics of hydrogen oxidation reaction. Int $\mathrm{J}$ Hydrogen Energy 35:12878-12887

[20] Mayrhofer KJJ, Hartl K, Juhart V, Arenz M (2009) Degradation of Carbon-Supported Pt Bimetallic Nanoparticles by Surface Segregation. J Am Chem Soc 131:16348-16349

[21] Aguiar ACR, Olivi P (2010) Characterization and voltammetric behavior of $\mathrm{Pt}_{\mathrm{y}} \mathrm{Mo}_{\mathrm{z}} \mathrm{O}_{\mathrm{x}} / \mathrm{C}$ electrodes prepared by the thermal decomposition of polymeric precursors. J Power Sources 195:3485-3489

[22] Lebedeva NP, Janssen GJM (2005) On the preparation and stability of bimetallic PtMo/C anodes for proton-exchange membrane fuel cells. Electrochim Acta 51:29-40

[23] Dos Anjos DM, Kokoh KB, Léger JM, De Andrade AR, Olivi P, Tremiliosi-Filho G (2006) Electrocatalytic oxidation of ethanol on Pt-Mo bimetallic electrodes in acid medium. J Appl Electrochem 36:1391-1397 
[24] Mukerjee S, Urian RC (2002) Bifunctionality in Pt alloy nanocluster electrocatalysts for enhanced methanol oxidation and CO tolerance in PEM fuel cells: electrochemical and in situ synchrotron spectroscopy. Electrochim Acta 47:3219-3231

[25] Papakonstantinou G, Paloukis F, Siokou A, Neophytides SG (2007) The electrokinetics of $\mathrm{CO}$ oxidation on $\mathrm{Pt}_{4} \mathrm{Mo}(20 \mathrm{wt} \%) / \mathrm{C}$ interfaced with Nafion membrane. J Electrochem Soc 154(10):B989- B997

[26] Grgur BN, Markovic NM, Ross, PN (1999) The electro-oxidation of $\mathrm{H}_{2}$ and $\mathrm{H}_{2} / \mathrm{CO}$ mixtures on carbon-supported $\mathrm{Pt}_{\mathrm{x}} \mathrm{Mo}_{\mathrm{y}}$ alloy catalysts. J Electrochem Soc 146:1613-1619

[27] Hu JE, Liu Z, Eichhorn BW, Jackson GS (2012) CO tolerance of nano-architectured PtMo anode electrocatalysts for PEM fuel cells. Int J Hydrogen Energy 37:11268-11275

[28] Liu Z, Hu JE, Wang Q, Gaskell K, Frenkel AI, Jackson GS, Eichhorn B (2009) PtMo alloy and $\mathrm{MoO}_{\mathrm{x}} @ \mathrm{Pt}$ Core-Shell nanoparticles as highly CO-tolerant electrocatalysts. J Am Chem Soc 131:6924-6925

[29] Yan Z, Xie J, Jing J, Zhang M, Wei W, Yin S (2012) $\mathrm{MoO}_{2}$ nanocrystals down to $5 \mathrm{~nm}$ as Pt electrocatalyst promoter for stable oxygen reduction reaction. Int J Hydrogen Energy $37: 15948-15955$

[30] Martins PFBD, Ticianelli EA (2015) Electrocatalytic Activity and Stability of Platinum Nanoparticles Supported on Carbon-Molybdenum Oxides for the Oxygen Reduction Reaction. Chemelectrochem 2(9):1298-1306

[31] Ho VTT, Pan CJ, Rick J, Su WN, Hwang BJ (2011) Nanostructured $\mathrm{Ti}_{0.7} \mathrm{Mo}_{0.3} \mathrm{O}_{2}$ Support Enhances Electron Transfer to Pt: High-Performance Catalyst for Oxygen Reduction Reaction. J Am Chem Soc 133:11716-11724

[32] Nguyen TT, Ho VTT, Pan CJ, Liu JY, Chou HL, Rick J, Su WH, Hwang BJ (2014) Synthesis of $\mathrm{Ti}_{0.7} \mathrm{Mo}_{0.3} \mathrm{O}_{2}$ supported- Pt nanodendrites and their catalytic activity and stability for oxygen reduction reaction. Appl Catal B-Environ 154-155:183-189

[33] Esfahani RAM, Vankova SK, Monteverde Videla AHA, Specchia S (2017) Innovative carbon-free low content Pt catalyst supported on Mo-doped titanium suboxide $\left(\mathrm{Ti}_{3} \mathrm{O}_{5}-\mathrm{Mo}\right)$ for stable and durable oxygen reduction reaction. Appl Catal B-Environ 201:419-429

[34] Justin P, Rao GR (2011) Methanol oxidation on $\mathrm{MoO}_{3}$ promoted Pt/C electrocatalyst. Int J Hydrogen Energy 36:5875-5884 
[35] Wang Y, Fachini ER, Cruz G, Zhu Y, Ishikawa Y, Colucci JA, Cabrera CR (2001) Effect of surface composition of electrochemically codeposited platinum/molybdenum oxide on methanol oxidation. J Electrochem Soc 148:C222-C226

[36] Ordóñez LC, Roquero P, Ramírez J, Sebastian PJ (2016) Methanol Electro-Oxidation on Bimetallic PtMo/C Catalysts and Pt/C-Mo/C Mechanical Mixtures. Int J Electrochem Sci $11: 5364-5379$

[37] Gubán D, Borbáth I, Pászti Z, Sajó IE, Drotár E, Hegedüs M, Tompos A (2015) Preparation and characterization of novel $\mathrm{Ti}_{0.7} \mathrm{~W}_{0.3} \mathrm{O}_{2}-\mathrm{C}$ composite materials for Pt-based anode electrocatalysts with enhanced CO tolerance. Appl Catal B: Environ 174:455-470

[38] Gubán D, Pászti Z, Borbáth I, Bakos I, Drotár E, Sajó IE, Tompos A (2016) Design and preparation of CO tolerant anode electrocatalysts for PEM fuel cells. Period Polytech Chem 60(1):29-39

[39] Borbáth I, Pászti Z, Gubán D, Vass Á, Tompos A (2015) CO-toleráns anódoldali elektrokatalizátor fejlesztése PEM tüzelőanyag-cellákhoz. Magyar Kémiai Folyóirat 121:8088

[40] Gubán D, Tompos A, Bakos I, Vass Á, Pászti Z, Szabó EG, Sajó IE, Borbáth I (2017) Preparation of CO-tolerant anode electrocatalysts for polymer electrolyte membrane fuel cells. Int J Hydrogen Energy 42:13741-13753

[41] Vass Á, Borbáth I, Pászti Z, Bakos I, Sajó IE, Németh P, Tompos A (2017) Effect of Mo incorporation on electrocatalytic performance of Ti-Mo mixed oxide-carbon composite supported Pt electrocatalysts. React Kinet Mech Cat 121:141-160

[42] Fairley N (2006) "CasaXPS: Spectrum Processing Software for XPS, AES and SIMS," Version 2.3.13, Casa Software Ltd, Cheshire. http://www.casaxps.com

[43] Micoud F, Maillard F, Gourgaud A, Chatenet M (2009) Unique CO-tolerance of Pt-WO materials. Electrochem Commun 11:651-654

[44] Guillén-Villafuerte O, García G, Rodríguez JL, Pastor E, Guil-López R, Nieto E, Fierro JLG (2013) Preliminary studies of the electrochemical performance of Pt/X@ $\mathrm{MoO}_{3} / \mathrm{C}(\mathrm{X}=$ $\mathrm{Mo}_{2} \mathrm{C}, \mathrm{MoO}_{2}, \mathrm{Mo}^{0}$ ) catalysts for the anode of a DMFC: Influence of the Pt loading and Mophase. Int J Hydrogen Energy 38:7811-7821.

[45] Tsiouvaras N, Martínez-Huerta MV, Paschos O, Stimming U, Fierro JLG, Peña MA (2010) PtRuMo/C catalysts for direct methanol fuel cells: Effect of the pretreatment on the 
structural characteristics and methanol electrooxidation. Int J Hydrogen Energy 35:1147811488

[46] Samjeske G, Wang H, Löffler T, Baltruschat H (2002) CO and methanol oxidation at Ptelectrodes modified by Mo. Electrochim Acta 47:3681-3692

[47] Mukerjee S, Lee SJ, Ticianelli EA, McBreen J, Grgur BN, Markovic NM, Ross PN, Giallombardo JR, De Castro ES (1999) Investigation of enhanced CO tolerance in proton exchange membrane fuel cells by carbon supported PtMo alloy catalyst. Electrochem Solid State Lett 2(1):12-15

[48] Pereira LGS, Paganin VA, Ticianelli EA (2009) Investigation of the CO tolerance mechanism at several Pt-based bimetallic anode electrocatalysts in a PEM fuel cell. Electrochim Acta 54:1992-1998

[49] Hou Z, Yi B, Yu H, Lin Z, Zhang H (2003) CO tolerance electrocatalyst of PtRu$\mathrm{H}_{\mathrm{x}} \mathrm{MeO}_{3} / \mathrm{C}(\mathrm{Me}=\mathrm{W}, \mathrm{Mo})$ made by composite support method. J Power Sources 123:116-125

[50] Song C, Khanfar M, Pickup PG (2006) Mo oxide modified catalysts for direct methanol, formaldehyde and formic acid fuel cells. J Appl Electrochem 36:339-345

[51] Alcaide F, Álvarez G, Tsiouvaras N, Pena MA, Fierro JLG, Martínez-Huerta MV (2011) Electrooxidation of $\mathrm{H}_{2} / \mathrm{CO}$ on carbon-supported $\mathrm{PtRu}-\mathrm{MoO}_{\mathrm{x}}$ nanoparticles for polymer electrolyte fuel cells. Int J Hydrogen Energy 36:14590-14598

[52] Micoud F, Maillard F, Bonnefont A, Job N, Chatenet M (2010) The role of the support in $\mathrm{CO}_{\mathrm{ads}}$ monolayer electrooxidation on Pt nanoparticles: $\mathrm{Pt} / \mathrm{WO}_{\mathrm{x}}$ vs. Pt/C. Phys Chem Chem Phys 12:1182-1193

[53] Zhang H, Wang Y, Fachini ER, Cabrera CR (1999) Electrochemically Codeposited Platinum/Molybdenum Oxide Electrode for Catalytic Oxidation of Methanol in Acid Solution. Electrochem Solid State Lett 2(9):437-439

[54] Guillén-Villafuerte O, Guil-López R, Nieto E, García G, Rodríguez JL, Pastor E, Fierro JLG (2012) Electrocatalytic performance of different Mo-phases obtained during the preparation of innovative Pt-MoC catalysts for DMFC anode. Int $\mathrm{J}$ Hydrogen Energy 37:7171-7179

[55] Baltrusaitis J, Mendoza-Sanchez B, Fernandez V, Veenstra R, Dukstiene N, Roberts A, Fairley N (2015) Generalized molybdenum oxide surface chemical state XPS determination via informed amorphous sample model. Appl Surf Sci 326:151-161 
[56] Schroeder T, Zegenhagen J, Magg N, Immaraporn B, Freund HJ (2004) Formation of a faceted $\mathrm{MoO}_{2}$ epilayer on Mo(112) studied by XPS, UPS and STM. Surf Sci 552:85-97

[57] Scanlon DO, Watson GW, Payne DJ, Atkinson GR, Egdell RG, Law DSL (2010) Theoretical and Experimental Study of the Electronic Structures of $\mathrm{MoO}_{3}$ and $\mathrm{MoO}_{2}$. J Phys Chem C 114:4636-4645

[58] Zhu Y, Uchida H, Watanabe M (1999) Oxidation of Carbon Monoxide at a Platinum Film Electrode Studied by Fourier Transform Infrared Spectroscopy with Attenuated Total Reflection Technique. Langmuir, 15, 8757-8764

[59] Igarashi H, Fujino T, Zhu Y, Uchida H, Watanabe M (2001) CO Tolerance of Pt alloy electrocatalysts for polymer electrolyte fuel cells and the detoxification mechanism. Phys Chem Chem Phys 3:306-314

[60] Uchida H, Ozuka H, Watanabe M (2002) Electrochemical quartz crystal microbalance analysis of CO-tolerance at Pt-Fe alloy electrodes. Electrochim. Acta 47:3629-3636

[61] Kanezashi I, Nohara S, Omura J, Watanabe M, Uchida H (2011) Electrochemical quartz crystal microbalance analysis of the $\mathrm{CO}$ oxidation reaction at $\mathrm{Pt}$ alloy electrodes, J. Electroanal. Chem. 662:123-129

[62] Anderson AB, Neshev NM (2002) Mechanism for the Electro-oxidation of Carbon Monoxide on Platinum, Including Electrode Potential Dependence. J Electrochem Soc 149:E383-E388

[63] Watanabe M, Zhu Y, Uchida H (2000) Oxidation of CO on a Pt-Fe Alloy Electrode Studied by Surface Enhanced Infrared Reflection-Absorption Spectroscopy. J. Phys. Chem. B 104:1762-1768

[64] Beden B, Lamy C, De Tacconi NR, Arvia AJ (1990) The electrooxidation of CO: A test reaction in electrocatalysis. Electrochim. Acta 35:691-704

[65] Lu J, Li WS, Du JH, Fu JM (2005) Co-deposition of $\mathrm{Pt}-\mathrm{H}_{\mathrm{x}} \mathrm{MoO}_{3}$ and its catalysis on methanol oxidation in sulfuric acid solution. J New Mat Electrochem Systems 8:5-14

[66] Saji VS, Lee CW (2012) Molybdenum, molybdenum oxides, and their electrochemistry. ChemSusChem 5(7):1146-1161 